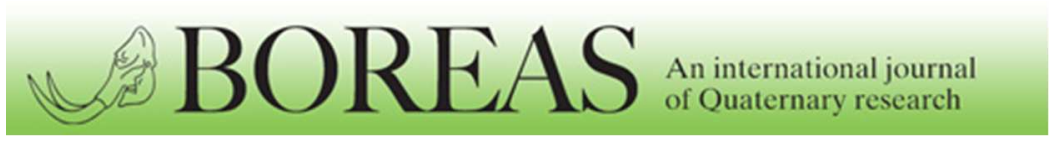

\title{
Holocene vegetation change in northernmost Fennoscandia and the impact on prehistoric foragers 12 000-2000 cal. a BP - A review
}

\begin{tabular}{|r|l|}
\hline Journal: & Boreas \\
\hline Manuscript ID & BOR-029-2018.R2 \\
\hline Manuscript Type: & Original Article \\
\hline Date Submitted by the Author: & n/a \\
\hline Complete List of Authors: & $\begin{array}{l}\text { Sjøgren, Per J.; UiT Norges arktiske universitet, Tromsø University Museum } \\
\text { Damm, Charlotte; UiT Norges arktiske universitet, Department of } \\
\text { Archaeology, History, Religious Studies and Theology }\end{array}$ \\
\hline Keywords: & $\begin{array}{l}\text { Arctic, Fennoscandia, Holocene, Hunter-gatherer, Norway, Stone Age, } \\
\text { Vegetation change, Foragers }\end{array}$ \\
\hline
\end{tabular}




\section{Holocene vegetation change in northernmost Fennoscandia and the impact on prehistoric foragers 12 000-2000 cal. a BP - A review}

\section{PER SJÖGREN AND CHARLOTTE DAMM}

Sjögren, P. \& Damm, C.: Holocene vegetation change in northernmost Fennoscandia and the impact on prehistoric foragers 12 000-2000 cal. a BP - A review. Boreas xxxx

While single pollen records are widely used in reconstructing the environment for nearby prehistoric settlements, they are less helpful when addressing large scale issues of variation in human settlement patterns. In order to assess the impact of vegetation change on regional prehistoric settlement- and subsistence patterns in an ecotone sensitive area, we inferred the general change in main vegetation types based on palaeobotanical investigations from across northernmost Fennoscandia. Tundra vegetation was predominant during the Lateglacial and earliest parts of the Holocene. Maritime birch forests rich in ferns started to expand c. 11000 cal. a BP and became dominant from 10000 cal. a BP. Pine expanded from the NE of the investigation area and pine-birch forest dominated in the inland around 8000 cal. a BP. A gradual degeneration of forest towards more open birch woodland started c. $6000 \mathrm{cal}$. a BP with the most marked change around $3500 \mathrm{cal}$. a BP. Along the northern outer coast this eventually led to open heathland. Comparison with the archaeological setting suggests a general correlation between low forest cover and extensive mobility patterns, while widespread and varied forest cover appear to have led to a more sedentary way of life. The background for this is arguably that the forested landscapes hosted a larger diversity of resources within a shorter foraging distance, while areas and periods with low forest cover required longer travels to obtain the desired prey and materials.

PerSjögren (per.sjoegren@uit.no), Tromsø University Museum, UiT - The Arctic University of Norway, Lars Thøringsvei 10, N-9037 Tromsø, Norway; Charlotte Damm, Department of Archaeology, History, Religious Studies and Theology, UiT - The Arctic University of Norway, Breivika, N-9037 Tromsø, Norway 
Recently there has been a surge in the interest in demographic analyses in archaeology. This is the case also for Fennoscandia and early prehistoric periods (e.g. Tallavaara et al. 2010; Tallavaara \& Seppä 2011; Apel et al. 2017; Manninen et al. 2017). Much of the recent research has specifically investigated links between demographic fluctuation and environmental change at a supra-regional scale, rather than at site level. However, comprehensive overviews of the environmental variation are lacking for many regions, including the far north. In the following we seek to remedy this situation by presenting a synthesis of available vegetation reconstructions from across the northernmost part of Fennoscandia, here defined as the Norwegian counties of Finnmark and northern Troms, including adjacent areas in northern Finland (Fig. 1). This will provide the background for investigations of regional demographic variation and resource exploitation in forager communities as observed from archaeological data.

The northernmost region of Fennoscandia has a very rich and well documented archaeological record of hunter-fishers spanning most of Holocene period. The area was colonised shortly after the beginning of the Holocene, but farming and herding of any scale was introduced only in the course of the last 1000 years. The region has one of the highest densities of preserved prehistoric house-pits remains found in temperate and arctic regions. This may partially be attributed to the open landscape, limited accumulation of soils and negligible disturbance by agriculture and development, leaving house-pits both easy to detect and relatively intact. Northernmost Fennoscandia thus provides a rather unique opportunity for studies of temporal and spatial demographic patterns, looking into, amongst other issues, relative population fluctuations (Jørgensen 2018), and demographic distribution. In both cases it is pertinent to ask to what extent temporal change was related to either climatic and environmental conditions or socio-cultural factors.

The majority of the dwelling remains are situated along the coast, suggesting a subsistence based predominantly on marine resources. The relatively sparse faunal evidence from archaeological sites supports a prehistoric emphasis on marine resources, notably codfish and seal. Other resources exploited were reindeer, elk, and birds in addition to smaller mammals (Helskog 1983; Engelstad 1984; Renouf 1989; Hodgetts 2010). Archaeological evidence of the exploitation of wood and plants is typically only available through charcoal.

As in recent history, plants were probably of secondary importance as subsistence in prehistoric northern Fennoscandia (Günther et al. 2018: supplement S1 text), but they might have been important for key nutrients such as vitamin C (Bergman et al. 2004), and a 
welcome culinary supplement. The presence of different plant material, especially wood, was on the other hand critical as fuel for heat, light and procurement of food (Damm 2016). It delivered raw material for essential equipment such as hunting and fishing tools and containers, as well as for constructions such as boats, sledges, hunting traps and shelter (e.g. Kuokkanen 2000; Callanan 2013; Koivisto \& Nurminen 2015; Bjerck 2016). Trees also provided natural shelter and could be integrated in traps or guiding fences. The vegetation, especially if forested or not, was also crucial for over-land mobility and line-of sight. Particular stands of trees or even individual trees may have functioned as way points. For example, the dark evergreen pine stand out clearly amongst the lighter birch, particularly in winter. Finally the vegetation is a crucial part of the habitat for various types of animals in different seasons, which could play an important role not just in subsistence, but also as provider of skins, bone and antler, all vital for the livelihood in the far north. Some of the most important species in the northern terrestrial fauna are reindeer and elk, who prefer somewhat different habitats. Other game animals are brown bears, beaver, hares and various game hunted mostly for the fur (e.g. fox, wolf; Helskog 1983; Engelstad 1984: Renouf 1989; Hodgetts 2010).

Reconstructions of the local vegetation based on pollen analyses are available from a large number of sites. However, in order to obtain a broader understanding of the supraregional landscape these hunter-gatherers inhabited, and how this may have affected their settlement patterns and population size, an overview of the temporal and spatial environmental diversity is required. Rather than focus on the environment in the relative vicinity of the sites and any direct human impact on this, a reconstruction of the regional variations is sought in order to provide a background to the choices made with regard to settlement patterns: which environments and resources were available, what were the prehistoric preferences, and did vegetation change affect demographic factors such as population distribution?

Here we use intuitively (non-numerically) interpreted pollen records to compile and summarise past vegetation development and diversity in northernmost Fennoscandia. We want the results to be easily accessible for non-palynologists, in addition to serve as an overview for specialists unfamiliar with this area. In addition to depicting the general development in vegetation we also want to show the spatial variation in this development. To achieve this aim we identify a number of vegetation types, with which vegetation developments and patterns can be characterised. This approach does not allow gradual 
change, minor (but potentially important) taxa and the uncertainty attached to the data and interpretations to be presented in as much detail as they ideally should. Still, considering the quantity, variation and complexity of the available data we consider this the best way to achieve a dense general overview. The present synthesis thus aims to present the broader lines of vegetation history and variation of the region.

\section{Regional overview}

The Norwegian Atlantic Current brings warm Atlantic water north along the coast and the predominant westerlies bring mild air inland, providing a comparably mild climate considering the location north of the Arctic circle. This moderating effect on the climate lessens towards the east as well as in the interior. Precipitation at the west coast is high, at the outer islands more than $1500 \mathrm{~mm} \mathrm{a}^{-1}$, but decline towards the east with coastal precipitation below $750 \mathrm{~mm} \mathrm{a}^{-1}$ east of Magerøya island (Dannevig \& Harstveit 2013). The Scandes mountain range running along the west coast partly shelters the inland from the moist westerlies, bringing inland precipitation down below $500 \mathrm{~mm} \mathrm{a}^{-1}$. The coastal climate is maritime with mild summers and winters, although temperatures decline towards the east. Troms $\varnothing$ at the SW edge of the investigation area has a mean July temperature of $12{ }^{\circ} \mathrm{C}$ and a mean January temperature of $-4{ }^{\circ} \mathrm{C}$, while Vardø at the far NE coast has a July temperature of $9{ }^{\circ} \mathrm{C}$ and mean January temperature of $-5^{\circ} \mathrm{C}$ (1961-1990, https://www.met.no/). Precipitation in Tromsø is $1030 \mathrm{~mm} \mathrm{a}^{-1}$ and in Vardø only $560 \mathrm{~mm} \mathrm{a}^{-1}$. The inland is drier and show higher seasonal variation with warmer summers and colder winters. At Karasjok in the inland mean July temperature is $13{ }^{\circ} \mathrm{C}$ and mean January temperature $-17^{\circ} \mathrm{C}$, and precipitation $370 \mathrm{~mm} \mathrm{a}^{-1}$. The main climatic gradients in the area are thus along the coast with wetter and warmer conditions in the SW and colder and drier conditions in the NE, and from coast to inland with larger seasonal temperature variations (especially colder winters) and drier conditions in the inland.

Today most of the study area is covered by mountain heathland or barren ground, although birch forest/woodland dominates in fjord areas, valleys and lowlands, and in dry inland valleys pine forests are common. Birch woodland is common along the Finnish border but is replaced by pine forest in the SE. North-Boreal vegetation dominates in the lowland and Alpine vegetation at some altitude, while the Middle Boreal zone is limited to the inner coast/fjord area of the SW part of the investigation area, and Arctic conditions (in the 
bioclimatic sense) only occur along the NE coast. The forest limit is highest in the interior SW part of the investigation area, above $600 \mathrm{~m}$ a.s.l., and declines towards the coast and NE, falling to less than $300 \mathrm{~m}$ a.s.l. at the SW coast and with arctic, tree-less areas at the NE coast (Moen 1999).

It is important to note that the present investigation primarily reflects past changes in lowland vegetation (the present Boreal and Arctic zones). There are three reasons for this. Firstly, these areas are the most interesting from a human perspective as settlement and activities are concentrated here; secondly, most of the palaeorecords are from lowland areas; and thirdly, high-altitude pollen records are difficult to interpret and local altitudinal differences would complicate the presentation.

\section{From pollen records to vegetation classes}

The present synthesis is based on previously intuitively (non-nummerically) intepreted palaeobotanical records. However, in order to allow direct comparison between records some reintepretation and/or reformulation has been necessary. As many records as feasible were included to provide as a complete picture as possible of both the data available and the past vegetation change. Nevertheless, some records were dismissed as i) they only covered as short period of time (c. $<2000$ years); ii) were associated with problems as (very) uncertain dating or hiatuses; iii) were not suitable for inferring local low-land dry-ground vegetation, for example high altitude sites or very large mires; or iv) were not or only partially published. In total we found 59 pollen records relevant for the present synthesis (Table 1, Fig. 1). The pollen data were interpreted as published, with accompanying variation in the quality, but in all cases comprehensive pollen percentage diagrams were available. The position of all sites were determined or checked against present digital maps (Kartverket, www.norgeskart.no; National land survey of Finland, http://www.maanmittauslaitos.fi; accessed 2017).

The chronologies follow the original publications as far as possible. Published noncalibrated ${ }^{14} \mathrm{C}$ dates were calibrated with OxCal 4.3. (Bronk Ramsay 2009) using the IntCal 13 calibration curve (Reimer et al. 2013). The record ages are presented as calibrated ${ }^{14} \mathrm{C}$ years (cal. a BP) before 1950 CE. If only depth-scale was available linear interpolation/extrapolation between calibrated radiocarbon dates was used in order to date zone-borders. The number of ${ }^{14} \mathrm{C}$ dates varies between records, and in older investigations bulk dates were used, with less reliable results than the more recent high resolution AMS 
dates. We have made no corrections for this disparity in quality of the depth-age relationship between records, although the number of dates are provided in Table 1 to allow for some estimation of the dating quality. The only exception is Østervatnet (Prentice 1981) were the basal bulk ${ }^{14} \mathrm{C}$ dates clearly have been contaminated by dolomitic clasts in tillite and here the zone-dates of Holmfjellvatnet (Prentice 1982) are applied by correlation. Notably, basal bulk ${ }^{14} \mathrm{C}$ dates in the region are prone to hard-water effect and may be too old (Prentice 1981; Seppä 1996). This might affect other sites as well, and the earliest records may display too old dates, although we have not been able to determine which and too what degree. In addition, correct dating of the uppermost part of peat or lake sediment are perilous (Sjögren et al. 2007), and are not uncommonly disregarded and ignored as uninteresting, which has resulted in uncertain chronologies for the past 1000 years in many records.

The original zonation and interpretation of the pollen records are adhered to when they aimed to depict local dry-land vegetation and are compatible with the vegetation classes applied here. In several cases though, the aims of the original interpretation differed from the present and accordingly also the basis for zonation, in which cases the pollen data have been re-interpreted directly. When the original interpretation/zonation was kept it was always checked directly with the pollen-data in order to provide internally coherent interpretations. Vegetation reconstruction based on pollen data are well explained and discussed elsewhere (e.g. von Post 1916; Tauber 1965; Prentice 1985; Fægri \& Iversen 1989; Jackson 1994) and here we will only mention two aspects that pose special challenges for pollen interpretation in the present region: Firstly, some of the most common pollen-types are difficult to distinguish from each other, i.e. tree-birch pollen (Betula pubescens-type) from dwarf-birch pollen (Betula nana-type), and crowberry-type (Empetrum-type) from billberry-type pollen (Vaccinium-type, or more generally Ericales-type). How well and to what degree these are separated may vary between analysts. Secondly, it may be challenging to determine to what degree the pollen assemblage represents local ( 20-200 m; see Prentice 1985) vegetation as compared to stand-scale $(\sim 0-20 \mathrm{~m}$ ) and regional (beyond $\sim 2 \mathrm{~km}$ ). Many plants growing on the mires are also important constituents of the dry-land vegetation (e.g. crowberry, dwarfbirch and grasses), and sites in open terrain with little local pollen production may receive relatively large amounts of regional tree-pollen. Pollen accumulation rates (PAR), and/or macrofossils are useful to determine if and to what degree a taxa is locally present, but these types of data are not available for all sites. These potential biases have been carefully 
considered when interpreting the pollen data/results, but all uncertainties could not be mitigated.

Based on the palaeobotanical investigations and present vegetation we concluded that the use of eleven main vegetation classes and four sub-classes were most suitable to describe the change in vegetation as perceived in the palaeobotanical records, see Table 2 . The vegetation types used here largely correspond to modern vegetation types (see Fremstad 1997; Moen 1999; Walker et al. 2005), although not in a strict sense.

\section{Results and interpretation}

The Holocene changes in vegetation types at the individual sites are presented in Fig. 2, sorted in three transects from west to east following the outer coast, the fjord area and the inland. The schematic vegetation development has been summarised in Table 3 as characteristic vegetation-type per millennia. A comparison with the general climatic development is provided in Table 4. Below the most important features of the vegetation development and associated climate change are compared with the known demographic changes in the region.

\section{The tundra period - pioneer settlement (14 000-10 000 cal. a BP)}

The outer coast of northern Norway started to emerge from the ice around $15000 \mathrm{cal}$. a BP, and at the start of the Younger Dryas cold period c. $12700 \mathrm{cal}$. a BP the ice had retreated to the inner fjord area. There the ice-front halted or possibly re-advanced to the TromsøLyngen/Main sub-stage, some 50-100 km inland from the outer coast (Fig. 1). At the beginning of the Holocene, $11700 \mathrm{cal}$. a BP the ice started to retreat again, more rapidly in the east than in the Scandes to the west (Stroeven et al. 2016; Romundset et al. 2017). The last remains of the Scandinavian Ice Sheet in the Scandes Mountains melted away around 9100 cal. a BP (Cuzzone et al. 2016). Integrated summer insolation peaked around $11000 \mathrm{cal}$. a BP $\left(70^{\circ} \mathrm{N}\right.$, Huybers 2006; Huybers \& Eisenman 2006), and insolation alone would suggest warmer summers and colder winters.

Pollen records dating back to the earliest deglaciated areas are scant (sites \#20, 34), but those that do imply that tundra vegetation prevailed c. 14 000-13 000 cal. a BP., which is in line with investigations further south in northern Norway (Elverland \& Alm 2012; Birks et al. 2014). The earliest commonly recorded vegetation-type in northernmost Fennoscandia is a 
steppe tundra vegetation characterised by an abundance of mugworth (Artemisa) pollen, in the period between c. 13000 to 12 000/11 500 cal. a BP, which coincides with the cold Younger Dryas period (12 700-11 700 cal. a BP). Birks 2015 and Birks et al. 2012 argue that most if not all mugworth pollen were long-distance transported from the southeast. That would infer extremely low local pollen productivity, which in turn would mean a very harsh climate and sparse vegetation. A very cold late Younger Dryas with polar desert vegetation (in the broad sense, i.e. very cold and dry) is also recorded at Andøya just south of the investigation area (Vorren et al. 2009). Subsequently, the steppe-tundra changed into shrub-tundra. In this early period many radiocarbon dates are uncertain, but the main change seemed to have occurred $c$. 11500 cal. a BP, marking the start of the Holocene period (11700 cal. a BP). This early Holocene shrub-tundra period shows a very clear succession from an early phase were willow dominated (Salix sp.) to a late phase were crowberry dominated (Ericales/Empetrum). Different dates of the onset suggest that this change was caused by natural succession following the ice-retreat and soil maturation rather than directly initiated by general climate change, although as noted above radiocarbon dates are notoriously uncertain in this early period. Notably, temperatures inferred from lake macrofossils are considerably higher than the terrestrial vegetation would suggest (Väliranta et al. 2015).

The pioneer foragers that arrived at the coast of northernmost Fennoscandia 11 500-11 000 years ago encountered an open shrub-tundra landscape with willow thickets and dwarf shrubs. There was a general lack of trees, but birch trees might be found in more sheltered areas and expanded from 11000 cal. a BP onwards. The limited stands of birch trees must have stood out in the landscape, pointing out sheltered locations. However, many human settlements were located on exposed locations. The terrestrial fauna must have been limited to arctic species adapted to the tundra environment, such as reindeer which immigrated from the east (Kleppe 2014, 2018). The marine productivity was nonetheless high (Breivik 2014), and the locations of early Mesolithic settlement sites strongly indicate reliance on marine resources. While some of these pioneers may have arrived from the east or south-east (Kleppe 2018), other early foragers journeyed north along the Atlantic coast and must have used boats as their primary means of transportation (Bjerck 2016). The open landscape allowed for good visibility from the boat or on land, helping to locate favourable landscape elements, such as rivers and lakes for fresh water and fresh water fishing (although the availability of these at this time is underexplored). Similarly, fauna could be more easily spotted and pursued in that 
landscape, possibly much in the same way as reindeer hunts were conducted on the tundra in Greenland (Grønnow 2009).

Charcoal from archaeological sites demonstrate that shrubs such as willow and presumably dwarf birch were used in fires. It is likely that the limited number of larger trees and branches were initially reserved for construction of boats, shelters and for instance spear shafts, all crucial equipment which required larger and stronger pieces of wood. The presence of charcoal from pine suggests that driftwood was also employed. Nevertheless the lack of trees constrained the possibilities for more substantial buildings, and all remains from this earliest phase appear to be tents, using a limited amount of wood for the construction (Fretheim 2018). The many small sites in exposed locations on islets and peninsulas with limited access to fresh water in themselves indicate a highly mobile settlement pattern. This is enhanced when considering the vegetation, which would have required travels for wood for equipment and to areas supporting terrestrial mammals.

\section{The early Holocene birch period - new immigration and inland exploitation (10 000-8000 cal. a BP)}

Starting c. 11000 cal. a BP the shrub-tundra began to give away to rich birch forests in the fjord areas and to open birch woodland in more exposed coastal areas, especially early in the NE. In the NW coastal area macrofossils of tree-birch (Betula pubescens) have been found at Sørøya and dated to $10400 \mathrm{cal}$. a BP (10 490-10 230 20), from Nordkinn dated to $10600 \mathrm{cal}$. a BP (10 730-10 440 20) (Romundset et al. 2011) and near Hammerfest at 10200 cal. a BP (Birks et al. 2012), which confirms the expansion seen in the pollen records (\#11, 14, 20). In the inland birch forest was not established until around 10000 cal. a BP, likely an effect of the much later deglaciation of this area. The early Holocene birch forests were rather homogenous across the region with an undergrowth dominated by ferns and grasses (meadow/fern type), although in the western part of the investigation area tall herbs, especially meadowsweet (Filipendula ulmaria) were common (\#7, 11, 14, 36, 37). At about $10000 \mathrm{cal}$. a BP the birch forests were fully established across the region. July solar insolation was approaching its highest values (peaking 10 000-9000 cal. a BP; Berger 1978; Berger \& Loutre 1991) and the warm Atlantic water dominated as far north as Svalbard 10 200 cal. a BP (Mangerud \& Svendsen 2018). On the other hand, the Scandinavian Ice Sheet in the western mountain area (final deglaciation c. 9100 cal. a BP; Cuzzone et al. 2016) as well 
as the Laurentide Ice Sheet in America (final deglaciation c. 6700 cal. a BP; Ullman et al. 2016) still had a chilling effect on the climate.

Pine first became established on the Varanger-Nordkinn area around 10000 cal. a BP and then spread parallel to the pattern of deglaciation, i.e. from N-NE to S-SW (see Seppä 1996; Seppä \& Hammarlund 2000). An overview of the regional expansion and decline in pine and alder as seen in the relative pollen values is provided in Fig. 3, were the early expansion in the NNE $(\# 23,24)$ is evident (note that here only the general relative abundance of the taxa is indicated, not the local vegetation cover). Around the Varanger fjord (\#42-44) pine-birch forest was also established very early (10 000-9000 cal. a BP). Archeological finds of pine charcoal from Virdnejávri $\sim 45 \mathrm{~km}$ inland from Alta (site 40) have been dated to $c .9600$ cal. a BP (Ua-46463, Skandfer, pers. comm. 2018), which shows that minor stands of pine was established, and utilized, in the inland well before the general expansion of pine in these areas. Macrofossils of pine (Pinus sylvestris) also indicate it was present in northwestern Finland from 9500 cal. a BP onwards (Väliranta et al. 2015). Similarly, in Dividalen, inland Troms, a pine needle dates to 9700 cal. a BP (interpolated, Jensen et al. 2002), and further south in the Scandes pine tree line peaked 9600/9500-9000 cal. a BP (Kullman 2013; Kullman \& Öberg 2015; Paus \& Haugland 2017). From the north coast of the Kola peninsula pine is evident from c. 8900 cal. a BP (Snyder et al. 2000).

As noted above the NE region was favoured with an early expansion of birch woodland, birch forest and pines. This region is also rich in early Holocene archaeological sites (Blankholm 2018; Kleppe 2018), although at present it is unclear if this is a result higher detection rate caused by the present low vegetation cover and high research activity, or whether it is in fact evidence for higher prehistoric population density.

At c. 10000 cal. a BP the archaeological data indicate a migration across land from present day Russian territory into northern Finland and onto the NE coast of the investigation area (Rankama \& Kankanpää 2008; Sørensen et al. 2013; Damlien 2016; Günther et al. 2018). From the following centuries a number of sites from the inland in both northern Finland and Norway give evidence for a more extensive use of terrestrial resources in the birch woodland and forests (Halinen 2005; Hood 2012). At the few sites with faunal remains, reindeer dominate (Rankama \& Ukkonen 2001; Ukkonen 2004; Rankama \& Kankaanpää 2008), however rock art images suggest the presence of elk from at from at least 10000 cal. a BP (Gjerde 2010). While we know little about the push and pull factors for this migration event, the demographic patterns suggests that the immigrants not only introduced a new lithic 
technology, but also more extensive exploitation of terrestrial resources in the emerging woodland and forests. The majority of known settlements were still located on the coast in fjords and sounds, but the expanding boreal vegetation now became accessible even from the outer costal sites. While the pioneer settlement is generally presumed to be highly mobile, studies suggest that Middle Mesolithic populations (10 000-8500 cal. a BP) to a greater extent returned repeatedly to selected residential sites (Bjerck 1989; Grydeland 2000). Certainly these sites in the NE not only had good access to wood, but they also allowed short distance task group exploitation of a wide range of marine and terrestrial resources from within a geographically more limited area, allowing for a more varied subsistence. Notably the rock art was dominated by large terrestrial mammals such as reindeer and elk, demonstrating that while marine resources may have constituted the majority of the diet, the woodland and the species in it were prominent symbolically and in the cosmology.

\section{The pine period - interregional interaction and population increase (8000-4000 cal. a BP)}

Occasional mixed birch-pine forests started to occur already around 10000 cal. a BP, and small stands were present across the region 9500 cal. a BP, but the major expansion of pine occurred about 1500 years later. The 8200 cal. a BP cold event is present in some palaeoclimatic records from the region (Korhola et al. 2000; Bigler et al. 2003; Kullman 2013), although the impact on the vegetation is not clearly evident (Seppä et al. 2007). Around 8000 cal. a BP pine and mixed pine-birch forests became fully dominant in the inland and the inner fjords, with exception for the western fjord region where birch-alder forests were established at the same time. The expansion of pine from NE to SW as earlier documented by Seppä \& Hammarlund (2000; Figs 2, 3) have been interpreted as the onset of a dryer and more continental type of climate, which is also evident in other records (Table 4). Now the west-east differentiation became more pronounced as pine established itself as the dominant taxa in the inland and eastern inner coastal area, while alder became more common in the western fjord area. Along the outer coast the early Holocene birch forests/woodlands prevailed, although the rich undergrowth of grass and ferns disappeared.

There is little indication of any negative effects of the 8200 cal. a BP cold event on the human demographic patterns. Although the data are sparse, a gradual population increase from c. $8300-8200$ cal. a BP is indicated by a growing number of radiocarbon dates from charcoal found in archaeological contexts (Jørgensen 2018; Fig. 4). Similarly, the earlier 
Preboreal Oscillation 10 300-10 200 cal. a BP does not seem to have led to fewer human settlement sites, suggesting that there was no decrease in the human population (Breivik 2014). It should be noted though, that sites and radiocarbon dates from the 6th millennium $\mathrm{BCE}$ are relatively few in the study area. In addition, the 8200 cal. a BP cold event coincides with a technological shift away from the emphasis on pressure technique, microblades and high quality chert introduced around $10000 \mathrm{cal}$. a BP towards a more expedient technology with few diagnostic artefact types and extensive use of the readily available quartz (Damm 2006). In line with interpretations of a population collapse in the Late Pleistocene in southern Scandinavia (Riede 2008), such a technological shift could be the result of a dramatic event (in that case a volcanic eruption) that led to abrupt population decline and a loss of cultural and technological knowledge.

From about 8000 cal. a BP Summed Probability Distributions of radiocarbon dates suggests a steady population increase culminating in a peak just after $6000 \mathrm{cal}$. a BP (Jørgensen 2018; Fig. 4). There are some indications of increased use of the inland areas from c. 8000-6500 cal. a BP (Damm 2006; Hood in press). From about 7000 cal. a BP there is extensive evidence of strong contacts and interaction over long distances and across inland regions. The interregional contacts are evidenced in the spread of ceramic technology from the southeast into the easternmost part of our study area (Skandfer 2005, 2009), in the widespread use of slate for knives and projectile points, and in the explosion of rock art across Fennoscandia (Gjerde 2010). It has been suggested that the more open pine forest and the drier climate was better suited for long distance travel (Hicks \& Hyvärinen 1997).

The population growth towards 6000 cal. a BP coincided with the Holocene thermal maximum (Table 4), and the extensive and diverse vegetation supported a varied and probably more numerous terrestrial fauna. Elks thrive in forest habitats, and typically inhabit conifer forests, and although elk were present in the region well before the maximum extension of pine forests c. 8000-4000 cal. a BP (Hood 2012), there was likely a marked increase in the elk population during this period, as was certainly the case in northern Sweden (Larsson et al. 2012). At the sites in the study area with zooarchaeological data (all on the coast) both reindeer and elks are present, but never in large quantities, as marine resources dominate in the records (Helskog 1983; Engelstad 1984; Renouf 1989). The rock art also provides evidence of hunting of reindeer and elk (Helskog 2014). At present information on the distribution and prehistoric ecology of the ungulates has not been researched (for a more 
extensive discussion of the environmental impact on reindeer and elk populations at the Holocene thermal maximum see Hood in press).

The more extensive forests ensured plenty of wood for constructions and equipment. However, regional differences were pronounced in this period. The birch-pine forests were widespread in the east and at the heads of the fjords in the west, but were much sparser on the outer coast. At the fairly densely inhabited island of Sørøya, the pollen records (\#10-16) show that the vegetation was dominated by heathland and birch woodland. Since the records derive from the vicinity of settlements, it is possible that any woodland in these particular areas was depleted by human habitation. Still, they demonstrate very significant differences in the environment, between east and west, and from inner fjords to outer coastal areas. In the east a variety of both marine and terrestrial resources were available in short distances from settlements in mid and inner fjord regions, and settlements were indeed numerous here. Theis situation may have encouraged increased sedentism. However, also the outer regions of eastern fjords and in particular the sounds and outer coast of the west such as Sørøya (\#1016) and northern Troms (\#1-9, 31-37) appear to have been exploited intensively. This was most likely connected to the excellent year round fishing in these areas. Across the entire study area we find numerous house-pits, particularly from c. 6000 cal. a BP onwards. In the Sørøysund-region alone there is presently a record of more than 1400 house-pits, dating to between 7000-2000 cal. a BP (Vollan, pers. comm. 2018). These are remains of more substantial dwellings, which must indicate longer and repeated stays at the sites, with the foragers exploited a variety of resources from the local residence.

The different vegetation in east and west must have had noticeable impact on the choices made in each region with regard to obtaining and exploiting resources. Annual resource areas in the east could potentially have been relatively small with short-distance seasonal moves. However, in outer fjord areas and in the western parts of the region, medium range seasonal mobility may have been more likely, from the outer coast deeper into the fjords, in order to acquire both a range of wood and the species living in the woodlands and forests established there. It would also have led to a potential for increased specialisation and exchange between groups primarily exploiting outer coast and inner fjords respectively (seal, whale and walrus products for elks and furs for instance), which may be part of the interaction documented more directly in the archaeological record. 
The modelled population increase (Jørgensen 2018; Fig. 4) is noticeable also in the outer coastal region in the west. In other words, the difference in vegetation does not appear to have had a negative impact on population size.

A similar and contemporary peak at $6000 \mathrm{cal}$. a BP is recorded for southern and central Finland, but surprisingly not for northern Finland (Tallavaara et al. 2010). In northern Norway and central Finland, this peak was followed by a distinct decline from c. 5600 cal BP (Tallavaara et al. 2010; Jørgensen 2018). The population growth correlates well with the generally positive environmental development, such as presumed increase in species diversity and quantities, reducing risk in flexible foraging groups able to exploit a range of resources. The decline is more difficult to explain, and certainly does not appear to be directly linked to any marked change in the vegetation, although it correlates with the start of the woodland degeneration on the northern coast and a general decline in summer temperatures, with a potential cold spell / abrupt cooling around 5500 cal. a BP (e.g. Magny \& Haas 2004; Sommer et al. 2009; Alsos et al. 2016). In addition, one may have to look to the marine environmental change (Jørgensen 2018).

\section{The late Holocene birch and heathland period - changes in settlement dynamics and population decline (4000-2000 cal. a BP)}

The climate started to deteriorate after 6000 cal. a BP, likely an effect of declining summer insolation and associated weakening of the northbound Atlantic currents (e.g. Andersen et al. 2004; Seppä et al. 2009). In the NE coastal region a development towards a more cold adaptive vegetation is evident already from $7000 \mathrm{cal}$. a BP, but a more general change in this direction was first initiated around $6000 \mathrm{cal}$. a BP. Pine and alder slowly gave way to birch, with exception of the western part were pine was established late. Tall-herb vegetation undergrowth changed into meadow-type that in turn developed into heath-type undergrowth. Birch forest was reduced to more open birch woodland, which along the northern outer coast changed into heathland. Still, many of the vegetation types established around 8000 cal. a BP prevailed until c. 3500 cal. a BP when numerous records indicate a change towards modern conditions, even though the development continued until at least $2000 \mathrm{cal}$. a BP. The general development towards a vegetation more adapted to a colder and wetter type of climate is seen as a slow increase of mire species such as crowberry (Empetrum nigrum), cloudberry (Rubus chamaemorus), half grasses (Cyperaceae) and bog mosses (Sphagnum), here exemplified in Fig. 5. The tree-line started to creep southward and the most significant change for human 
settlement would be along the northernmost coast as the birch woodland gave way to open heathland. Still, birch woodland prevailed in more sheltered areas, especially in the west.

Local human impact is evident in many records as increased values of grasses and many herbs, especially sorrels (Rumex sp.), although in prehistoric times seldom to a degree that directly altered the main vegetation type. Examples of clear anthropogenic changes of the landscape are the grassy vegetation types occurring at Breivik (\#13) and Skjervika 1 (\#19). In the south-western coastal area large-scale human impact is more evident, and an anthropogenic opening of the landscape occurred from c. 1000 cal. a BP, when birch at several locations gave away to open grass-, meadow-, or heath vegetation (\#6, 13-15, 32, 36, 45). A further and more general increase in land-use occurred during the past few centuries, with grassland expanding at the expense of birch from c. 200 cal. a BP $(\# 1,10,17,19,39)$ Most likely this late increase in human impact started with the 18th century post Little Ice Age establishment of fishing villages and culminated with the major population increase of the 19 th century.

In the study region the population appears to have grown again, with a peak around 4000 cal. a BP before yet another marked decline from c. 3500 cal. a BP (Jørgensen 2018; Fig. 4), present also for northern Finland (Tallavaara et al. 2010). The peak coincided with a phase of sedentism for some, but not all local groups, i.e. at least some members of a residential group lived year round at one site. This is indicated by zooarchaeological evidence (Hodgetts 2010), and by the many very large house-pits with extensive middens from the period 4400-3500 cal. a BP. However, the peak also appears to coincide with a marked increase in hunting pits for reindeer in the interior (Hood in press), demonstrating seasonal exploitation of the terrestrial fauna, and possibly indicating a declining elk population in favour of an expanding reindeer population caused by the retreating pine forests.

The potential decline in human population 3500 cal. a BP was roughly contemporary with a more rapid change in vegetation. By now the retreat of pine and birch resulted in a vegetation comparable to the present day, although many palaeoclimatic records indicate that the effective precipitation increased already 4500-4000 cal. a BP (Hyvärinen \& Alhonen 1994; Eronen et al. 1999; Korhola et al. 2005; Vorren et al. 2012; Balascio \& Anderson 2016). It appears that the extensive sedentism practiced was now abandoned in favour of a more mobile settlement pattern again, as demonstrated in the now often less substantial dwellings, and settlements at what is clearly seasonal sites for salmon fishing, fresh water fishing and inland hunting (Olsen 1994; Blankholm 2011). It is, however, hard to see why this 
rapid but not abrupt change should have had such a dramatic impact on population size and mobility. Previous research has instead argued for social and cultural reasons (Olsen 1994; Schanche 1994). It is of course possible that vegetation changes caused alterations in specific local habitats (e.g. for elk) and in reindeer migration routes, which then required a return to seasonal relocation. For northern Sweden it has been argued that overexploitation of elk eventually lead to increased focus on reindeer, and hence instigated a more mobile lifestyle, mirroring the shift from hunting of the stationary elk to the migratory reindeer (Forsberg 1989; Larsson et al. 2012). Extensive hunting of elk in combination with a retreat of the pine forest might have caused a population collapse, at least locally. While neither elk nor reindeer are prominent in the archaeological faunal remains further north, the majority of identifiable bones may have been left at hunting stations, and not brought back to the main settlements, thus leaving fewer traces.

During the first millennia BCE agriculture started to influence the area, at least in the southwest (Vorren 1983, 2005a; Sjögren 2009; Sjögren \& Arntzen 2013), which might have had an direct impact on the demography (Jørgensen 2018; Fig. 4) if not the general vegetation. The cultural repertoire that we recognised as directly linked to the historical Saami population in the region developed in the centuries around the start of the Common Era (Hansen \& Olsen 2004). Starting in the medieval period there was also an increased influence from the surrounding states (Norway-Denmark, Sweden-Finland and Russia) and Christianity. The increase in details and complexity of the cultural development the past 2000-3000 years brings it beyond the scope and temporal resolution of the present investigation.

\section{Conclusions}

The use of general vegetation classes based on existing palaeobotanical records allowed us to compose a synthesis that simultaneously demonstrates the regional, sub-regional and local variation in the main vegetation development. Despite significant local variability there is a general development from early Holocene tundra, to maritime birch forest, to pine forest and finally to the late Holocene birch-ericales woodlands and heathlands. On the sub-regional scale the NE part experienced the first establishment and expansion of pine and alder, but also suffered the earliest degeneration of woodland into open heathland, which likely affected the population distribution in the area. During the early tundra period as well as along the outer 
coast in the late Holocene there would have been a shortage of wood, which is also evident in the archaeological material. The abundance, trek patterns and type of game, i.e. elk vs. reindeer, would largely depend on the presence of pine or birch forest. Overall, a more extensive forest cover with pine in the inland and fjord areas and birch readily available at the coast would have allowed a more sedentary way of life, with shorter seasonal relocation distances. Sparse forest cover would demand more extensive mobility patterns as local wood resources were depleted faster and the distance between inland game hunting grounds and the rich marine resources at the coast increased. In the present investigation, we focused on the impact on prehistoric society by vegetation in an ecotone sensitive area. For a more complete picture the direct effect of climate change, variation in marine resources, cultural and technological aspect also need to be considered. In this sense the present investigation is a contribution to both a more comprehensive assessment of Stone Age demographics and for the identification of causes and effects.

\title{
Acknowledgements
}

The authors wish to thank colleagues at the Arctic University in Norway, and in particularly members of the Sub-Arctic Stone Age Research Group (SARG), for input and discussions. Erlend Kirkeng Jørgensen allowed us to reproduce his SPD results for the region. Information about potential pollen-sites was compiled together with Antony Brown and Inger Greve Alsos. Two anonymous reviewers have contributed with insightful comments and improvements for the final version. This publication is a contribution to the project Stone Age Demographics supported by the Research Council of Norway (grant number 261760).

\section{References}

\author{
Allen, J. R. M., Long, A. J. , Ottley, C. J., Pearson, D. G. \& Huntley, B. 2007: Holocene \\ climate variability in northernmost Europe. Quaternary Science Reviews 26, 1432 \\ 1453.
}

Alsos, I. G., Sjögren, P., Edwards, M. E., Landvik, J. Y., Gielly, L., Forwick, M., Coissac, E., Jakobsen, L. V., Føreid, M. K. \& Pedersen, M. W. 2016. Sedimentary ancient DNA from Lake Skartjørna, Svalbard: assessing the resilience of arctic flora to Holocene climate change. The Holocene 26, 627-642. 
Andersen, C., Koç, N., Jennings, A. \& Andrews, T. 2004: Nonuniform response of the major surface currents in the Nordic Seas to insolation forcing: Implications for the Holocene climate variability. Paleoceanography 19, doi:10.1029/2002PA000873.

Apel, J., Wallin, P., Storå, J. \& Possnert, G. 2017: Early Holocene human population events on the island of Gotland in the Baltic Sea (9200-3800 cal. a BP). Quarternary International 465, $276-286$.

Balascio, N. L. \& Anderson, R. S. 2016: Paleoenvironmental analysis of Hollabåttjønnen Bog, Skarpeneset Peninsula, Tønsnes, Norway. In Nergaard, R. H., Oppvang, J. \& Cerbing, M. (eds.): Tønsnes havn, Tromsø kommune, Troms - Rapport fra de arkeologiske undersøkelsene 2014. Tromura 45, 191-214.

Barnekow, L. 2000: Holocene regional and local vegetation history and lake-level changes in the Torneträsk area, northern Sweden. Journal of Paleolimnology 23, 399-420.

Berger, A. L. 1978: Long-term variations of caloric insolation resulting from the earth's orbital elements. Quaternary Research 9, 139-167.

Berger, A. \& Loutre, M.F. 1991: Insolation values for the climate of the last 10 million of years. Quaternary Sciences Review 10, 297-317.

Bergman, I., Östlund, L \&, Zackrisson, O. 2004: The use of plants as regular food in ancient subarctic economies: a case study based on Sami use of Scots Pine innerbark. Arctic Anthropology 41, 1-13.

Bigler, C., Larocque, I., Peglar, S. M., Birks, H. J. B. \& Hall, R. I. 2002: Quantitative multiproxy assessment of long-term patterns of Holocene environmental change from a small lake near Abisko, northern Sweden. The Holocene 12, 481-496.

Bigler, C., Grahn, E., Larocque, I., Jeziorski, A. \& Hall, R. 2003: Holocene environmental change at Lake Njulla (999 m a.s.1.), northern Sweden: a comparison with four small nearby lakes along an altitudinal gradient. Journal of Paleolimology 29, 13-29.

Birks, H.H. 2015: South to north: Contrasting late-glacial and early-Holocene climate changes and vegetation responses between south and north Norway. The Holocene 25, 37-52. 
Birks, H. H., Jones, V. J., Brooks, S. J., Birks, H. J. B., Telford, R. J., Juggins, S. \& Peglar, S. M. 2012: From cold to cool in northernmost Norway: Lateglacial and early Holocene multi-proxy environmental and climate reconstructions from Jansvatnet, Hammerfest. Quaternary Science Reviews 33, 100-120.

Birks, H. H., Aarnes, I., Bjune, A. E., Brooks, S. J., Bakke, J., Kühl, N. \& Birks, H .J. B. 2014: Lateglacial and early-Holocene climate variability reconstructed from multiproxy records on Andøya, northern Norway. Quaternary Science Reviews 89, 108 122.

Bjerck, H. B. 1989: Mesolithic Site Types and Settlement Patterns at Vega, Northern Norway. Acta Archaeologica 60, 1-32.

Bjerck, H. B. 2016: Settlements and Seafaring: Reflections on the Integration of Boats and Settlements Among Marine Foragers in Early Mesolithic Norway and the Yámana of Tierra del Fuego. The Journal of Island and Coastal Archaeology 12, 276-299.

Bjune, A. E., Birks, H. J. B. \& Seppä, H. 2004: Holocene vegetation and climate history on a continental-oceanic transect in northern Fennoscandia based on pollen and plant macrofossils. Boreas 33, 211-223.

Blankholm, H. P 2011. Plugging the Gap: Early Metal Age in the Ostu Mountain Pass, Troms, Northern Norway. Fennoscandia Archaeologica XXVIII, 19-38.

Blankholm, H. P. 2018: Macro-level Predictive Modelling of Early Stone Age Pioneer Settlement Locations in Varanger, Northern Norway. In Blankholm, H.P. (ed.): The Early Economy and Settlement in Northern Europe. Pioneering, Resource Use, Coping with Change. 77-102. The Early Settlement of Northern Europe, vol. 3. Equinox, Sheffield.

Breivik, H. M. 2014: Palaeo-oceanographic development and human adaptive strategies in the Pleistocene-Holocene transition: A study from the Norwegian coast. The Holocene 24, $1478-1490$.

Bronk Ramsey, C. 2009: Bayesian analysis of radiocarbon dates. Radiocarbon 51, 337-360.

Callanan, M. E. 2013: Melting snow patches reveal Neolithic archery. Antiquity 87, 728-745. 
Chistyakova, N. O., Ivanova E. V., Risebrobakken, B., Ovsepyan, E. A. \& Ovsepyan Y. S. 2010: Reconstruction of the Postglacial Environments in the Southwestern Barents Sea Based on Foraminiferal Assemblages. Marine Geology 50, 608-617.

Cuzzone, J. K., Clark, P. U., Carlson, A. E., Ullman, D. J., Rinterknecht, V. R., Milne, G. A., Lunkka, J.-K., Wohlfarth, B., Shaun, A., Marcott, S. A. \& Caffee, M. 2016: Final deglaciation of the Scandinavian Ice Sheet and implications for the Holocene global sea-level budget. Earth and Planetary Science Letters 448, 34-41.

Damlien, H. 2016: Eastern pioneers in westernmost territories? Current perspectives on Mesolithic hunter-gatherer large-scale interaction and migration within Northern Eurasia. Quaternary International 419, 5-16.

Damm, C. 2006: Interregional Contacts across Northern Fennoscandia 6000-4000 BC. In Arneborg, J. \& Grønnow, B. (eds.): Dynamics of Northern Societies. Proceedings of the SILA/NABO Conference on Arctic and North Atlantic Archaeology, 199-208. PNM, Publications from the National Museum, Studies in Archaeology and History 10, Copenhagen.

Damm, C. 2016: Enfolded by the long winter`s night. In: Dowd, M. \& Hensey, R. (ed.): The Archaeology of Darkness, 107-116. Oxbow Books, Oxford.

Dannevig, P. \& Harstveit, K. 2013: Klima i Norge. I Store norske leksikon. https://snl.no/Klima_i_Norge

Elverland, E. \& Alm, T. 2012: High resolution macrofossil analysis of Late Weichselian Arctic lacustrine sediments on Andøya, northern Norway. In Elverland, E.: Late Weichselian to early Holocene vegetation and bird activity on Andøya, Nordland County, 54 pp. Ph.D. thesis, UiT - The Arctic University of Norway. Available online: https://munin.uit.no/handle/10037/4565.

Elverland, E. \& Vorren, K. -D. 2008: 7500 yr of mire-pool development and the history of Pinus sylvestris (L.) in Sub-Arctic coastal Norway. Review of Palaeobotany and Palynology 150, 48-58.

Engelstad, E. 1984. Diversity in Arctic Maritime Adaptation. An Example from the Late Stone Age of Arctic Norway. Acta Borealia 2, 3-24. 
Eronen, M. \& Hyvärinen, H. 1981: Subfossil pine dates and pollen diagrams from northern Fennoscandia. Geologiska Föreningens i Stockholm Förhandlingar 103, 437-445.

Eronen, M., Hyvärinen, H. \& Zetterberg, P. 1999: Holocene humidity changes in northern Finnish Lapland inferred from lake sediments and submerged Scots pines dated by tree-rings. The Holocene 9, 569-580.

Fægri, K. \& Iversen, J. 1989: Textbook of Pollen Analysis. 328 pp. Wiley and Sons, Chichester.

Fimreite, S. 1980: Vegetasjonshistoriske og palaeolimnologiske undersøkelser i Tromsø, Nord-Norge, fra Sen Weichsel og Holocen. Cand. real. thesis, UiT - The Arctic University of Norway, $179 \mathrm{pp}$.

Fimreite, S., Vorren, K. -D. \& Vorren, T. O. 2001: Vegetation, climate and ice-front oscillations in the Tromsø area, northern Norway during the Allerød and Younger Dryas. Boreas 30, 89-100.

Forsberg, L. 1989: Economic and Social Change in the Interior of Northern Sweden 6000 BC. - 1000 AD. Larsson, T. \& Lundmark, H. (eds.): Approaches to Swedish Prehistory, 55-82. BAR International Series 500, Oxford.

Fremstad, E. 1997: Vegetasjonstyper i Norge. NINA Temahefte 12, 1-279.

Fretheim, S. E., Bjerck, H. B., Breivik, H. M. \& Zangrando, A. F. J. 2018: Tent, hut or house? A discussion on Early Mesolithic Dwellings proceeding from the site Mohalsen 2012II, Vega, Northern Norway. In Blankholm, H.P. (ed.): The Early Economy and Settlement in Northern Europe. Pioneering, Resource Use, Coping with Change, 207230. The Early Settlement of Northern Europe, vol. 3. Equinox, Sheffield.

Gjerde, J. M. 2010: Rock art and Landscapes. Studies of Stone Age rock art from Northern Fennoscandia. Ph.D.-thesis, UiT - The Arctic University of Norway, 505 pp. Available online: https://munin.uit.no/handle/10037/2741.

Grydeland, S. E. 2000: Nye perspektiver på eldre steinalder i Finnmark. En studie fra indre Varanger. Viking LXII, 10-50. 
Grønnow, B. 2009: Caribou Hunting Structures and Hunting Grounds of the Thule Culture in Angujaartorfiup Nunaa, West Greenland. In Grønnow, B. (ed.): On the Track of the Thule Culture from Bering Strait to East Greenland, 201-210. Publications from the National Museum. Studies in Archaeology \& History 5, Copenhagen.

Günther, T., Malmström, H., Svensson, E. M., Omrak, A., Sánchez-Quinto, F., Kilinc, G. M., Krzewinska, M., Eriksson, G., Fraser, M., Edlund, H., Munteres, A. R., Coutinho, A., Simões, L. G., Vicente, M., Sjölander, A., Sellevold, B. J, Jørgensen, R., Claes, P., Shriver, M. D., Valdiosera, C., Netea, M. G., Apel, J., Lidén, K., Skar, B., Storå, J., Götherström, A. \& Jakobsson, M. 2018: Population genomics of Mesolithic Scandinavia: Investigating early postglacial migration routes and high-latitude adaption. PLoS Biol 16, e2003703, doi.org/10.1371/journal.pbio.2003703.

Halinen, P. 2005: Prehistoric Hunters of Northernmost Lapland. Settlement patterns and subsistence strategies. ISKOS 14. 222 pp. Finnish Antiquarian Society, Helsinki.

Hammarlund, D., Barnekow, L., Birks, H. J. B., Buchardt, B. \& Edwards, T. W. D. 2002 Holocene changes in atmospheric circulation recorded in the oxygen-isotope stratigraphy of lacustrine carbonates from northern Sweden. The Holocene 12, 339351.

Hansen, L. I \& Olsen, B. 2014: Hunters in Transition. An Outline of Early Sámi History. 402 pp. Brill Publisher, Leiden.

Helskog, E. 1983. The Iversfjord Locality. A Study of Behavioural Patterning During the Late Stone Age of Finnmark, North Norway. Tromsø Museums Skrifter XIX, 162 pp.

Helskog, K. A. 2014. Communicating with the World of Beings. The World Heritage Rock Art Sites in Alta, Arctic Norway. 240 pp. Oxbow Books, Oxford.

Hodgetts, L. 2010 Subsistence Diversity in the Younger Stone Age Landscape of Varangerfjord, Northern Norway. Antiquity 84, 41-54.

Hicks, S. \& Hyvärinen, H. 1997: The Vegetation history of Northern Finland. Helsinki Papers in Archaeology 10, 25-34. 
Høeg, H. I. 2000: Pollenanalytiske undersøkelser i Finnmark, North Norway. AmS-Varia 37, 53-97.

Høeg, H. I. 2007: En pollenanalytisk undersøkelse på Tønsnes i Tromsø. 21 pp. Tromsø University Museum, Tromsø.

Hood, B. 2012: The Empty Quarter? Identifying the Mesolithic of Interior Finnmark, North Norway. Arctic Anthropology 49, 105-135.

Hood, B. in press. Settlement Models for Stone Age Inner Finnmark. In Skandfer, M., Blankholm, H.P. \& Hood, B. (eds.): From the Inside Looking Out: Archaeological Perspectyvies on Hunter-Gatherer Landscape and Resource Management in Interior North Norway. Equinox, Sheffield.

Huntley, B., Long, A. J. \& Allen, J. R. M. 2013: Spatio-temporal patterns in Lateglacial and Holocene vegetation and climate of Finnmark, northernmost Europe. Quaternary Science Reviews 70, 158-175.

Huybers, P. 2006: Early Pleistocene glacial cycles and the integrated summer insolation forcing. Science 313, 508-511.

Huybers, P. \& Eisenman, I. 2006: Integrated Summer Insolation Calculations. IGBP PAGES/World Data Center for Paleoclimatology Data Contribution Series \# 2006-079. NOAA/NCDC Paleoclimatology Program, Boulder CO, USA.

Hyvärinen, H. 1975: Absolute and relative pollen diagrams from northernmost Fennoscandia. Fennia 142, 1-23.

Hyvärinen, H. 1976: Flandrian pollen deposition rates and tree-line history in northern Fennoscandia. Boreas 5, 163-175.

Hyvärinen, H. 1985: Holocene pollen history of the Alta area, an isolated pine forest north of the general pine forest region in Fennoscandia. Ecologica Mediterranea, Tome XI (Fascicule 1), 69-71.

Hyvärinen, H. \& Alhonen, P. 1994: Holocene lake-level changes in the Fennoscandian treeline region, western Finnish Lapland: diatom and cladoceran evidence. The Holocene $4,251-258$. 
Jackson, S. T. 1994: Pollen and spores in Quaternary lake sediments as sensors of vegetation composition: theoretical models and empirical evidence. In Traverse, A. (ed.): Sedimentation of Organic Particles, 253-286. Cambridge University Press, Cambridge.

Jensen, C. 2004: The vegetation history of a coastal stone-age and iron-age settlement at $70^{\circ} \mathrm{N}$, Norway. Vegetation History and Archaeobotany 13, 269-284.

Jensen, C., Kuiper, J. G. J. \& Vorren, K. -D. 2002: First post-glacial establishment of forest trees: early Holocene vegetation, mollusc settlement and climate dynamics in central Troms, North Norway. Boreas 31, 285-301.

Jensen, C. \& Vorren, K. -D. 2008: Holocene vegetation and climate dynamics of the boreal alpine ecotone of northwestern Fennoscandia. Journal of Quaternary Science 23, 719743.

Jørgensen, E. K. 2018: The Palaeodemographic and environmental dynamics of prehistoric Arctic Norway: An overview of human-Climate Covariation. Quarternary International. https://doi.org/10.1016/j.quaint.2018.05.014

Kleppe, J. I. 2014: Desolate landscapes or shifting landscapes? Late glacial/early post-glacial settlement of northernmost Norway in the light of new data from Eastern Finnmark. In Riede, F. \& Tallavaara, M. (eds.) Lateglacial and Postglacial Pioneers in Northern Europe. 121-146. BAR International Series 2599. Oxbow Books, Oxford.

Kleppe, J. I. 2018: The Pioneer Colonisation of Northern Norway. In Blankholm, H.P. (ed.): The Early Economy and Settlement in Northern Europe. Pioneering, Resource Use, Coping with Change, 13-58. The Early Settlement of Northern Europe, vol. 3. Equinox, Sheffield.

Koivisto, S. \& Nurminen, K. 2015: Go with the flow: stationary wooden fishing structures and the significance of estuary fishing in subneolithic Finland. Fennoscandia Archaeologica XXXII, 55-77.

Korhola, A., Weckström, J., Holmström, L. \& Erästö, P. 2000: A quantitative Holocene climatic records from diatoms in northern Fennoscandia. Quaternary Research 54, 284-294. 
Kullman, L. 1999: Early Holocene tree growth at a high elevation site in the northernmost Scandes of Sweden (Lapland): a palaeobiographical case study based on megafossil evidence. Geografiska Annaler 81A, 63-74.

Kullman, L. 2013: Ecological tree line history and palaeoclimate - review of megafossil evidence from the Swedish Scandes. Boreas 42, 555-567.

Kullman, L. \& Öberg, L. 2015. New aspects of high-mountain palaeobiogeography: A synthesis of data from forefields of receding glaciers and ice parches in the Tärna and Kebnekaise mountains, Swedish Lapland. Arctic 68, 141-152.

Kuokkanen, T. 2000: Stone Age sledges of central-grooved type: Finnish reconstructions. Fennoscandia Archaeologica XVII, 37-56.

Larsson, T. B., Rosqvist, G., Ericsson, G. \& Heinrud, J. 2012. Climate Change, Moose and Humans in Northern Sweden 4000 cal. yr BP. Journal of Northern Studies 6, 9-30.

Magny, M. \& Haas, J. N. 2004: A major widespread climatic change around 5300 cal. yr BP at the time of the Alpine Iceman. Journal of Quaternary Science 19, 423-430.

Mangerud, J. \& Svendsen, J. I. 2018: The Holocene Thermal Maximum around Svalbard, Arctic North Atlantic; molluscs show early and exceptional warmth. The Holocene 28, $65-83$.

Manninen, M. A., Tallavaara, M. \& Seppä, H. 2017: Human responses to early Holocene climate variability in eastern Fennoscandia. Quarternary International 465, 287-297.

Moen, A. 1999: National Atlas of Norway: Vegetation. 200 pp. Norwegian Mapping Authority, Hønefoss.

Nilssen, E. 1993: Slettnes - pollenalytisk del. In Damm, C., Hesjedal, A., Olsen, B. \& Storli, I. (eds.): Arkeologiske undersøkelser på Slettnes, Sørøy 1991, 229-238. Tromura Kulturhistorie 23.

Olsen, B. 1994: Bosetning og samfunn i Finnmarks forhistorie. 158 pp. Universitetsforlaget, Oslo. 
Olsen, L., Reite, A., Riiber, K. \& Sørensen E. 1996: Finnmark County. Map of Quaternary Geology, Scale 1:500.000 with Description. Geological Survey of Norway, Trondheim.

Paus, A. \& Haugland, V. 2017: Early- and mid-Holocene forest-line and climate dynamics in southern Scandes mountains inferred from contrasting megafossil and pollen data. The Holocene 27, 361-383.

Prentice, H. C. 1981: A Late Weichselian and early Flandrian pollen diagram from Østervatnet, Varanger peninsula, NE Norway. Boreas 10, 53-70.

Prentice, H. C. 1982: Late Weichselian and early Flandrian vegetational history of Varanger peninsula, northeast Norway. Boreas 11, 187-208.

Prentice, I. C. 1985: Pollen representation, source area, and basin size: towards a unified theory of pollen analysis. Quaternary Research 23, 76-86.

Rankama, T. \& Ukkonen, P. 2001. On the early history of the wild reindeer (Rangifer tarandus L.) in Finland. Boreas 30, 131-147.

Rankama, T. \& Kankaanpää, J. 2008: Eastern arrivals in post-glacial Lapland: the Sujala site 10000 cal BP. Antiquity 82, 884-899.

Reimer, P. J., Bard, E., Bayliss, A., Beck, J. W., Blackwell, P. G., Bronk Ramsey, C., Grootes, P. M., Guilderson, T. P., Haflidason, H., Hajdas, I., Hatté, C., Heaton, T. J., Hoffmann, D. L., Hogg, A. G., Hughen, K. A., Kaiser, K. F., Kromer, B., Manning, S. W., Niu, M., Reimer, R. W., Richards, D. A., Scott, E. M., Southon, J. R., Staff, R. A., Turney, C. S. M. \& van der Plicht, J. 2013: IntCal13 and Marine13 Radiocarbon Age Calibration Curves 0-50,000 Years cal BP. Radiocarbon 55, 1869-1887.

Renouf, M. A. P. 1989. Prehistoric Hunter-Fishers of Varangerfjord, Northeastern Norway. 254 pp. BAR International Series 487. Archaeopress, Oxford.

Riede, F. 2008. The Laacher See-eruption (12,920 BP) and material culture change at the end of the Allerød in Northern Europe. Journal of Archaeological Science 35, 591-599.

Romundset, A., Akçar, N., Fredin, O., Tikhomirov, D., Reber, R., Vockenhuber, C., Christl, M. \& Schlüchter, C. 2017: Lateglacial retreat chronology of the Scandinavian Ice 
Sheet in Finnmark, northern Norway, reconstructed from surface exposure dating of major end moraines. Quaternary Science Reviews 177, 130-144.

Romundset, A., Bondevik, S. \& Bennike, O. 2011: Postglacial uplift and relative sea level changes in Finnmark, northern Norway. Quaternary Science Reviews 30, 2398-2421.

Schanche, K. 1994. Gressbakkentuftene i Varanger. Boliger og sosial struktur rundt 2000 $f . K r$. Doctoral thesis in archaeology. UiT - The Arctic University of Norway, $271 \mathrm{pp}$. Open online access: https://munin.uit.no/handle/10037/3317

Seppä, H. 1996: Post-glacial dynamics of vegetation and tree-lines in the far north of Fennoscandia. Fennia 174, 1-96.

Seppä, H., Birks, H. H. \& Birks, H. J. B. 2002a: Rapid climatic changes during the Greenland stadial 1 (Younger Dryas) to early Holocene transition on the Norwegian Barents Sea coast. Boreas 31, 215-225.

Seppä, H, Birks H. J. B., Giesecke, T., Hammarlund, D., Alenius, T., Antonsson, K., Bjune, A. E., Heikkilä, M., MacDonald, G. M., Ojala, A. E. K., Telford, R. J. \& Veski, S. 2007: Spatial structure of the $8200 \mathrm{cal}$ yr BP event in northern Europe. Climate of the Past 3, 225-236.

Seppä, H., Bjune, A. E., Telford, R. J., Birks, H. J. B. \& Veski, S. 2009: Last nine-thousand years of temperature variability in Northern Europe. Climate of the Past 5, 523-535.

Seppä, H. \& Hammarlund, D. 2000: Pollen-stratigraphical evidence of Holocene hydrological change in northern Fennoscandia supported by independent isotopic data. Journal of Paleolimnology 24, 69-79.

Seppä, H., Nyman, M., Korhola, A. \& Weckström, J. 2002b: Changes of treelines and alpine vegetation in relation to post-glacial climate dynamics in northern Fennoscandia based on pollen and chironomid records. Journal of Quaternary Science 17, 287-301.

Seppä, H. \& Weckström, J. 1999: Holocene vegetational and limnological changes in the Fennoscandian tree-line area as documented by pollen and diatom records from Lake Tsuolbmajavri, Finland. Écoscience 6, 621-635. 
Sjögren, P. 2009: Climate, cod and crops - Coastal land-use in the SW Barents Sea region during the past $2.5 \mathrm{ka}$. The Holocene 19, 703-716.

Sjögren, P. 2013: Pollenanlystiska undersökningar vid Skjærvika. In Henriksen, S. \& Valen, C.R. (eds.): Skjoervika og Fjellvika, Hammerfest kommune - Rapport fra de arkeologiske undersøkelsene 2009 og 2010. Tromura 43, 457-476.

Sjögren, P. \& Arntzen J. 2013: Agricultural practices in Arctic Norway the first millennium B.C. Vegetation History and Archaeobotany 22, 1-15.

Sjögren, P., van der Knaap, W. O., van Leeuwen, J. F. N., Andrič, M. \& Grünig, A. 2007: The occurrence of an upper decomposed layer or "Trockenhorizont", in the Alps and Jura Mountains. Mire and Peat 2, 1-14.

Skandfer, M. 2005: Early, northern Comb Ware in Finnmark: The concept of Säräisniemi 1 reconsidered. Fennoscandia Archaeologica XXII, 3-23.

Skandfer, M. 2009: "All Change?": Exploring the Role of technological Choice in the Early Northern Comb Ware of Finnmark, Arctic Norway. In Jordan, P. \& Zvelebil, M. (eds.): Ceramics Before Farming. The Dispersal of Pottery Among Prehistoric Eurasian Hunter-Gatherers, 347 - 374. Left Coast Press, Walnut Creek.

Skandfer, M. \& Høeg, H. I. 2012: Bácheveaj/Pasvikdalens elder historie belyst ved pollenanalyser og arkeologisk materiale. Viking $L X X V, 27-52$.

Snyder, J. A., MacDonald, G. M., Forman, S. L., Tarasov, G. A. \& Mode, W. N. 2000: Postglacial climate and vegetation history, north-central Kola Peninsula, Russia: pollen and diatom records from Lake Yarnyshnoe-3. Boreas 29, 261-271.

Sollid, J. L., Andersen, S., Hamre, N., Kjeldsen, O., Salvigsen, O., Stuerød, S., Tveitå, T. \& Wilhelmsen, A. 1973: Deglaciation of Finnmark, north Norway. Norsk Geografisk Tidsskrift 27, 234-325.

Sommer, R. S., Lindqvist, C., Persson, A., Bringsøe, H., Rhodin, A. G., Schneeweiss, N., Siroký, P., Bachmann, L. \& Fritz, U. 2009: Unexpected early extinction of the European pond turtle (Emys orbicularis) in Sweden and climatic impact on its Holocene range. Molecular Ecology 18, 1252-1262. 
Sørensen, M., Rankama, T., Kankaanpää, J., Knutsson, K., Knutsson, H., Melvold, S. A., Eriksen, B. V. \& Glørstad, H. 2013: The First Eastern Migrations of People and Knowledge into Scandinavia: Evidence from Studies of Mesolithic Technology, 9th8th Millennium BC. Norwegian Archaeological Review 46, 19-56.

Stroeven, A. P., Hättestrand, C., Kleman, J., Heyman, J., Fabel, D., Fredin, O., Goodfellow, B. W., Harbor, J. M., Jansen, J. D., Olsen, L., Caffee, M. W., Fink, D., Lundqvist, J., Rosqvist, G. C., Strömberg, B., Jansson, K. N. 2016: Deglaciation of Fennoscandia. Quaternary Science Reviews 147, 91-121.

Tallavaara, M., Pesonen, P. \& Oinonen, M. 2010. Prehistoric population history in eastern Fennoscandia. Journal of Archaeological Science 37, 251-260.

Tallavaara, M. \& Seppä, H. 2011: Did the mid-Holocene environmental changes cause the boom and bust of hunter-gatherer population size in eastern Fennoscandia? The Holocene 22, 215-223.

Tauber, H. 1965: Differential Pollen Dispersion and the Interpretation of Pollen Diagrams. 99 pp. C. A. Reitzels Forlag, Copenhagen.

Tveraabak, L. U. \& Alm, T. 1997: En pollenanalytisk undersøkelse av Sandvika pa Kvaløya (Tromsø kommune). Tromsø University Museum, Tromsø.

Ullman, D. J., Carlson, A. E., Hostetler, S. W., Clark, P. U., Cuzzone, J., Milne, G. A., Winsor, K. \& Caffee, M. 2016: Final Laurentide ice-sheet deglaciation and Holocene climate-sea level change. Quaternary Science Reviews 152, 49-59.

Ukkonen, P. 2004. Early in the North - Utilization of Animal Resources in Northern Finland during Prehistory. Iskos 13, 103-130.

Väliranta, M., Salonen, J.S., Heikkilä, M., Amon, L., Helmens, K., Klimaschewski, A., Kuhry, P., Kultti, S., Poska, A., Shala, S., Veski, S. \& Birks, H. H. 2015: Plant macrofossil evidence for an early onset of the Holocene summer thermal maximum in northernmost Europe. Nature communications 6, 6809, doi: 10.1038/ncomms7809. 
Von Post, L. 1916: Om skogsträdpollen i sydsvenska torvmosselagerföljder [Forest-tree pollen in south Swedish bog deposits]. Geologiska Föreningens $i$ Stockholm Förhandlingar 38, 384-390.

Vorren, K. -D. 1983: Den eldste korndyrking i det nordelige Norge. In Sandnes, J., Kjelland, A. \& Østerlie, I. (eds.): Folk of ressurser i nord - Foredrag fra Symposium om midtog nordskandinavisk kultur ved Universitetet i Trondheim. Norges loererhøgskole 2123 juni 1982, 11-47. Tapir, Trondheim.

Vorren, K. -D. 1985: Vegetasjonshistorien i gamle Helgøy herred, Troms, Nord-Norge. Med sarlig henblikk på menneskets innvirkning. Publikasjon nr. 9 fra Helgøyprosjektet, 93 pp. Universitet i Tromsø/NAVF, Tromsø.

Vorren, K. -D. 2001: Development of bogs in a coast-inland transect in northern Norway. Acta Palaeobotanica 41, 43-67.

Vorren, K. -D. 2002: Greipstad: Settlement history of the central farm of the northernmost Norse community during the Iron Ages. Norwegian Journal of Geography 56, 161173.

Vorren, K. -D. 2005a: Farm development at the cereal limit in northern - continuity and discontinuities. Vegetation History and Archaeobotany 14, 161-170.

Vorren, K. -D. 2005b: Stone Age settlements at Sørøya, sub-arctic Norway: impact on the vegetation. Vegetation History and Archaeobotany 14, 1-13.

Vorren, K. -D., Elverland, E., Blaauw, M., Ravna, E. K. \& Jensen, C. A. H. 2009: Vegetation and climate c. 12300-9000 cal. yr BP at Andøya, NW Norway. Boreas 38, 401-420.

Vorren, K.-D., Jensen, C. E. \& Nilssen, E. 2012: Climate changes during the last c. 7500 years as recorded by the degree of peat humification in the Lofoten region, Norway. Boreas 41, 13-30.

Walker, D. A., Raynolds, M. K., Daniëls, F. J. A., Einarsson, E., Elvebakk, A., Gould, W. A., Katenin, A. E., Kholod, S. S., Markon, C. J., Melnikov, E. S., Moskalenko, N. G., Talbot, S. S., Yurtsev, B. A., the other members of the CAVM Team12. 2005: The Circumpolar Arctic vegetation map. Journal of Vegetation Science 16, 267-282. 


\section{Figure captions}

Fig. 1. Site locations; see Table 1 for site information. Important place names mentioned in the text are shown. The red dashed line marks the ice margin of the "Tromsø-Lyngen" and "Main" deglaciation sub-stages (sensu Sollid et al. 1973; Olsen 1996), i.e. the late Younger Dryas ice margin stand-still or re-advance. After $11700 \mathrm{cal}$. a BP rapid deglaciation commenced, especially in the eastern parts.

Fig. 2. Holocene vegetation-type changes in northern Fennoscandia. Sites (Fig. 1) are sorted after three west-east transects following the outer coast, the fjord areas and the inland (some relocation has been made in order to enable shorter sequences to be placed after each another).

Fig. 3. Periods with maximum relative (\%) pollen values for alder (Alnus incana) and pine (Pinus sylvestris) indicating maximum occurrence in the regional vegetation. $(+)$ indicates that high pine values prevail after 3000 cal. a BP. Numbers refer to sites shown in Fig. 1.

Fig. 4. Relative fluctuation in prehistoric population for northernmost Norway indicated by Summed Probability Distribution (SPD) as determined by Jørgensen (2018). The SPD result is based on 873 binned radiocarbon dates (1205 individual determinations) from Finnmark and Northern Troms simulated against exponential population growth. Grey field marks the simulated 2 sigma statistical envelope of the exponential growth function. Positive deviation marked in red, negative deviation marked in blue. Reproduced with permission from Jørgensen (2018).

Fig. 5. Pollen proportions between selected taxa from Skjervika 2 (\#21) to illustrate the late Holocene paludification and heathland development. The general trend the past 5500 years at Skjervika 2 is decreasing pollen values of tree-birch (Betula pubescence-type) and the forestrelated herbs cow-wheat (Melampyrum) and meadowsweet (Filipendula ulmaria), while pollen values from dwarf-birch (Betula nana-type), crowberry/billberry (Ericales-type), cloudberry (Rubus chamaemorus) and grasses (Poaceae) increase. 


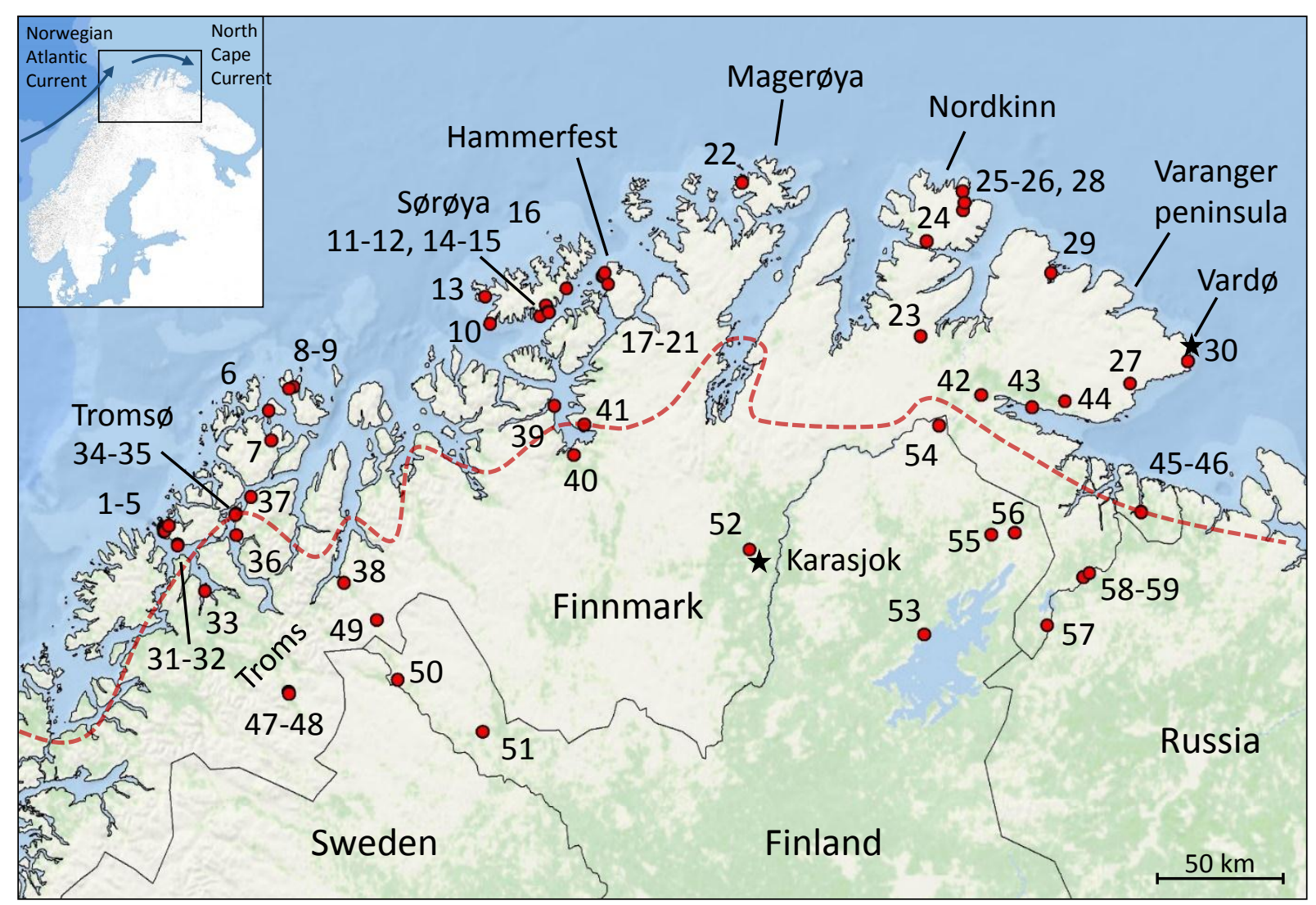




\section{Holocene vegetation-type changes} in northernmost Fennoscandia

17 Tundra types

18
$19 \square$ Tundra

$20 \square$ Steppe tundra

$21 \square$ Shrub tundra

$22 \square$ Shrub tundra

26 $\square$ Grass-meadow

$27 \square$ Grass-heathland

$29 \square$ Heathland

33 Forest types

$34 \square$ Birch woodland

$36 \square$ Birch forest

$37 \square$ Alder-birch forest

39 Pine-birch forest

43 Sub-types

44 $45_{--}^{-}$- heath type

$46 \square$ - meadow type

48 - tall-herb type

$49 \square$ - mire

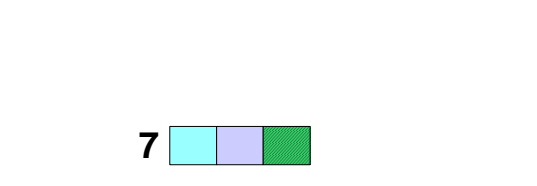

1

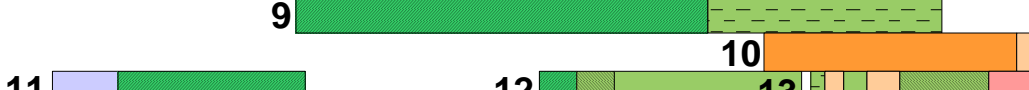

11
14

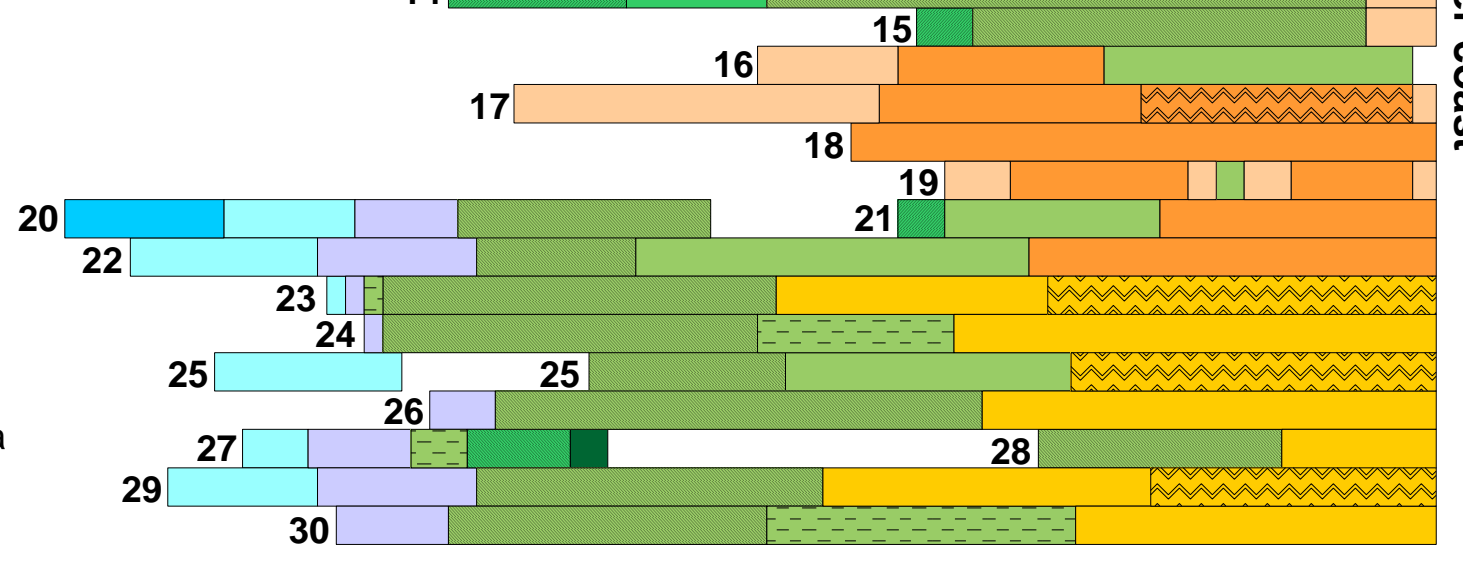

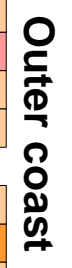
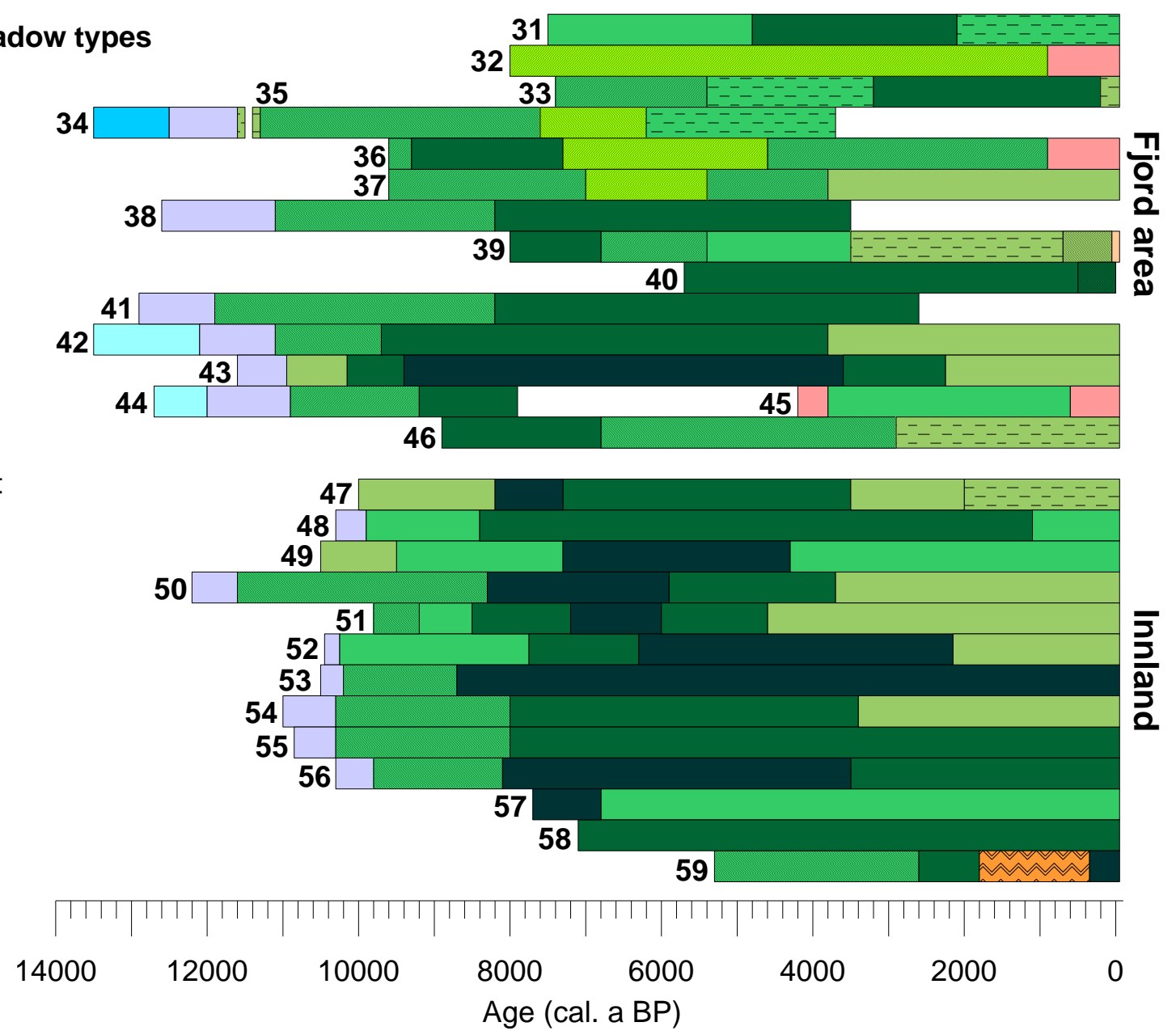
Jervtjern (47)

Gauptjern (48)

Dalmutladdo (49)

Tsuolbmajavri (51)

Skaidejavri (54)

Rautuselkä (55)

liten Cáhppesjávri (22)

Ifjord (23)

Hopseidet (24)

over Gunnarfj. (25)

over Kobbkrokv. (29)

Age

(cal. a BP) 10000

$8000 \quad 6000 \quad 4000$

Alder

Pine 
Page 35 of 40

Boreas

$$
\begin{aligned}
& 1 \\
& 2 \\
& 3 \\
& 4 \\
& 5 \\
& 6 \\
& 7 \\
& 8 \\
& 9 \\
& 10 \\
& 11 \\
& 12 \\
& 13 \\
& 14 \\
& 15 \\
& 16 \\
& 17 \\
& 18 \\
& 19 \\
& 20 \\
& 21 \\
& 22 \\
& 23 \\
& 24 \\
& 25 \\
& 26 \\
& 27 \\
& 28 \\
& 29 \\
& 30 \\
& 31 \\
& 32 \\
& 33 \\
& 34 \\
& 35 \\
& 36 \\
& 37 \\
& 38 \\
& 39 \\
& 40 \\
& 41 \\
& 42 \\
& 43 \\
& 44 \\
& 45 \\
& 46 \\
& 47 \\
& 48 \\
& 49 \\
& 50 \\
& 51 \\
& 52 \\
& 53 \\
& 54 \\
& 55 \\
& 56 \\
& 57 \\
& 58 \\
& 59 \\
& 60
\end{aligned}
$$

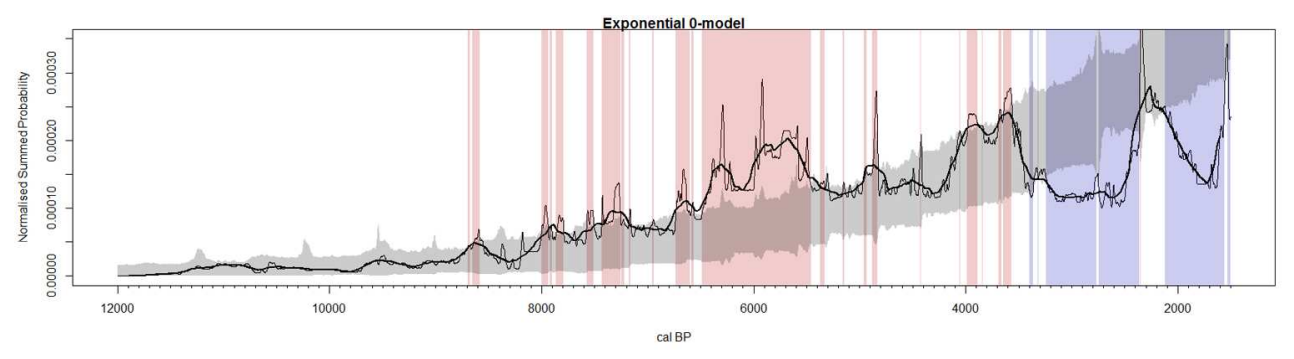



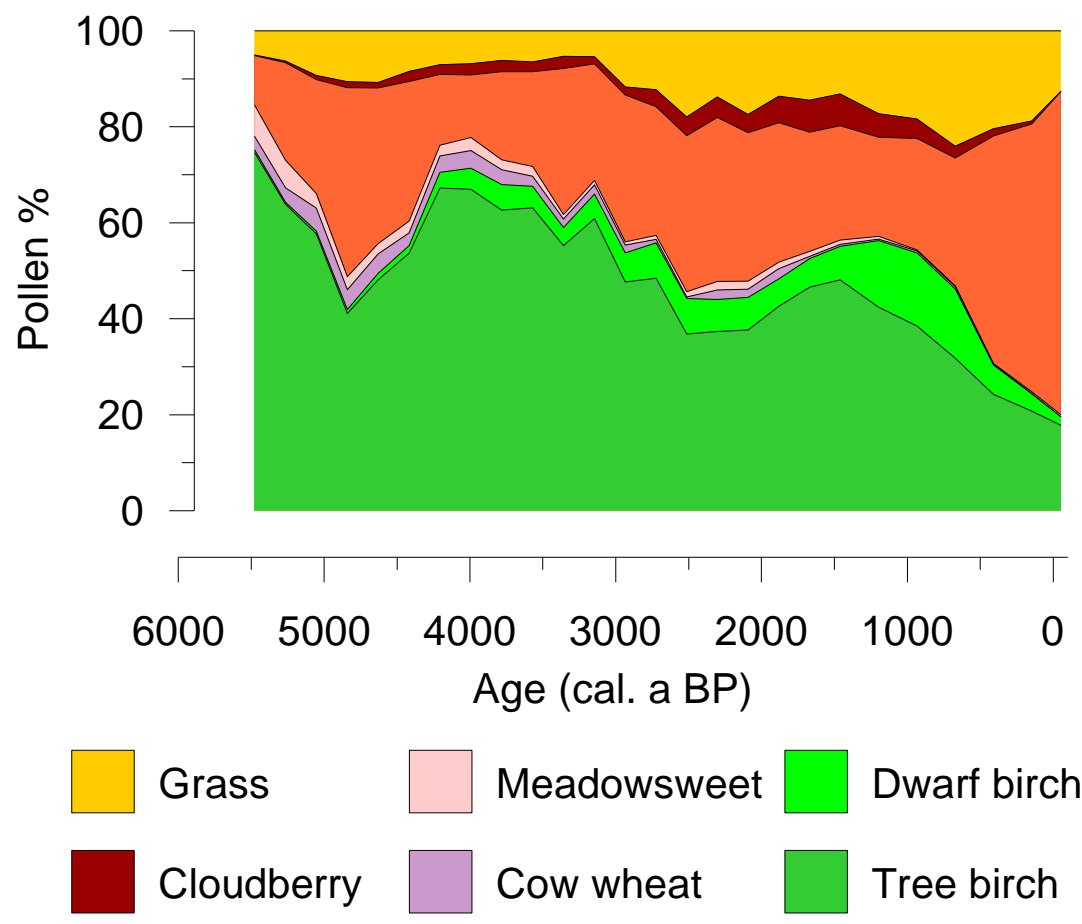

Crowberry, billberry 
Table 1. List of sites. Altitudes follow original publications. Proxy abbreviations: $\mathrm{P} \%=$ pollen percentage values; $\mathrm{PC}=$ pollen concentration values; $\mathrm{PAR}=$ pollen accumulation rates; $\mathrm{MF}=$ plant macrofossils; $\mathrm{H}=$ hard water effected.

\begin{tabular}{|c|c|c|c|c|c|c|c|c|}
\hline$\#$ & Site name & Lat. & Long. & $\mathrm{m}$ a.s.1. & Basin & Proxies & $\#^{14} \mathrm{C}$ & Reference \\
\hline \multicolumn{9}{|c|}{ Outer coast } \\
\hline 1 & Austeinmyra & $69^{\circ} 36^{\prime}$ & $18^{\circ} 02^{\prime}$ & 25 & mire & $\mathrm{P} \%$ & 9 & Vorren (2005a) \\
\hline 2 & Brensholmen & $69^{\circ} 35^{\prime}$ & $18^{\circ} 02^{\prime}$ & 11 & mire & $\mathrm{P} \%$ & 5 & Vorren (2005a) \\
\hline 3 & Austein 2 & $69^{\circ} 36^{\prime}$ & $18^{\circ} 02^{\prime}$ & 9 & mire & $\mathrm{P} \%$ & 4 & Vorren (2005a) \\
\hline 4 & Brensholmyra & $69^{\circ} 35^{\prime}$ & $18^{\circ} 03^{\prime}$ & 11 & mire & $\mathrm{P} \%$ & 3 & Vorren (2001) \\
\hline 5 & Sandvika 2 & $69^{\circ} 37^{\prime}$ & $18^{\circ} 06^{\prime}$ & 11 & mire & P\%, PAR & 4 & Tveraabak \& Alm (1997) \\
\hline 6 & Helgøy & $70^{\circ} 07^{\prime}$ & $19^{\circ} 22^{\prime}$ & 15 & mire & $\mathrm{P} \%$ & 5 & Vorren $(1985)$ \\
\hline 7 & Litlevatn & $70^{\circ} 13^{\prime}$ & $19^{\circ} 41^{\prime}$ & 24 & lake & $\mathrm{P} \%$ & 3 & Vorren (1985) \\
\hline 8 & Dåfjord 1 & $69^{\circ} 59^{\prime}$ & $19^{\circ} 24^{\prime}$ & 18 & mire & $\mathrm{P} \%$ & 1 & Vorren (1985) \\
\hline 9 & Vannreid & $70^{\circ} 12^{\prime}$ & $19^{\circ} 37^{\prime}$ & 15 & mire & $\mathrm{P} \%$ & 2 & Vorren (1985) \\
\hline 10 & Hasvik 1 & $70^{\circ} 29^{\prime}$ & $22^{\circ} 10^{\prime}$ & 16 & mire & $\mathrm{P} \%$ & 8 & Sjögren (2009) \\
\hline 11 & Husfjord 7 & $70^{\circ} 34^{\prime}$ & $22^{\circ} 53^{\prime}$ & 30 & mire & $\mathrm{P} \%$ & 1 & Vorren $(2005 b)$ \\
\hline 12 & Gåshopen & $70^{\circ} 31^{\prime}$ & $22^{\circ} 48^{\prime}$ & 12 & mire & $\mathrm{P} \%$ & 1 & Vorren (2005b) \\
\hline 13 & Breivik & $70^{\circ} 35^{\prime}$ & $22^{\circ} 06^{\prime}$ & 31 & mire & $\mathrm{P} \%$ & 4 & Sjögren (2009) \\
\hline 14 & Vatnan 1 & $70^{\circ} 32^{\prime}$ & $22^{\circ} 55^{\prime}$ & 18 & mire & $\mathrm{P} \%$ & 5 & Vorren (2005b) \\
\hline 15 & Vatnan 5 & $70^{\circ} 32^{\prime}$ & $22^{\circ} 55^{\prime}$ & 35 & mire & $\mathrm{P} \%$ & 3 & Vorren (2005b) \\
\hline 16 & Slettnes & $70^{\circ} 38^{\prime}$ & $22^{\circ} 08^{\prime}$ & 13 & mire & $\mathrm{P} \%$ & 3 & Nilssen (1993) \\
\hline 17 & Kilden & $70^{\circ} 41^{\prime}$ & $23^{\circ} 36^{\prime}$ & 15 & mire & $\mathrm{P} \%$, PAR & 5 & Jensen (2004) \\
\hline 18 & SUNDM & $70^{\circ} 41^{\prime}$ & $23^{\circ} 36^{\prime}$ & 19 & mire & $\mathrm{P} \%$ & 6 & Jensen (2004) \\
\hline 19 & Skjervika 1 & $70^{\circ} 42^{\prime}$ & $7038^{\prime}$ & 19 & mire & $\mathrm{P} \%, \mathrm{PAR}$ & 6 & Sjögren (2013) \\
\hline 20 & Jansvatnet & $70^{\circ} 39^{\prime}$ & $23^{\circ} 40^{\prime}$ & 53 & lake & $\mathrm{P} \%, \mathrm{PC}, \mathrm{MF}$ & 6 & Birks et al. (2012) \\
\hline 21 & Skjervika 2 & $70^{\circ} 42^{\prime}$ & $23^{\circ} 38^{\prime}$ & 32 & mire & $\mathrm{P} \%, \mathrm{PAR}$ & 3 & Sjögren (2013) \\
\hline 22 & liten Čáhppesjávri & $71^{\circ} 04^{\prime}$ & $25^{\circ} 22^{\prime}$ & 41 & lake & $\mathrm{P} \%,(\mathrm{PAR}), \mathrm{MF}$ & 21 & Huntley et al. (2013) \\
\hline 23 & Ifjord & $70^{\circ} 26^{\prime}$ & $27^{\circ} 38^{\prime}$ & 320 & lake & P\%, PAR & 5 & Seppä (1996) \\
\hline 24 & Hopseidet & $70^{\circ} 50^{\prime}$ & $27^{\circ} 43^{\prime}$ & 225 & lake & $\mathrm{P} \%, \mathrm{PAR}$ & 5 & Seppä (1996) \\
\hline 25 & over Gunnarfjorden & $71^{\circ} 02^{\prime}$ & $28^{\circ} 10^{\prime}$ & 73 & lake & $\mathrm{P} \%, \mathrm{PAR}, \mathrm{MF}$ & 12 & Allen et al. (2007) \\
\hline 26 & Momyra & $70^{\circ} 58^{\prime}$ & $28^{\circ} 10^{\prime}$ & 33 & mire & $\mathrm{P} \%$, PAR & 6 & Høeg (2000) \\
\hline 27 & Holmfjellvatnet & $70^{\circ} 14^{\prime}$ & $30^{\circ} 18^{\prime}$ & 230 & lake & $\mathrm{P} \%, \mathrm{PC}$ & 3 & Prentice (1982) \\
\hline 28 & Petterbuktmyra & $71^{\circ} 00^{\prime}$ & $28^{\circ} 11^{\prime}$ & 53 & mire & $\mathrm{P} \%, \mathrm{PAR}$ & 2 & Høeg (2000) \\
\hline 29 & over Kobbkrokvatnet & $70^{\circ} 42^{\prime}$ & $29^{\circ} 18^{\prime}$ & 51 & lake & $\mathrm{P} \%,(\mathrm{PAR}), \mathrm{MF}$ & 20 & Huntley et al. (2013) \\
\hline 30 & Domsvatnet & $70^{\circ} 20^{\prime}$ & $31^{\circ} 01^{\prime}$ & 120 & lake & $\mathrm{P} \%, \mathrm{PC}$ & 5 & Hyvärinen (1976) \\
\hline \multicolumn{9}{|c|}{ Fjord area } \\
\hline 31 & Lillevardhaugvatnet & $69^{\circ} 32^{\prime}$ & $18^{\circ} 12^{\prime}$ & 112 & lake & $\mathrm{P} \%, \mathrm{PAR}, \mathrm{MF}$ & 9 & Eleverland \& Vorren (2008) \\
\hline 32 & Greipstad 1 and 2 & $69^{\circ} 31^{\prime}$ & $18^{\circ} 13^{\prime}$ & 14 & mire & $\mathrm{P} \%$ & 6 & Vorren $(2002)$ \\
\hline 33 & Målsnes & $69^{\circ} 19^{\prime}$ & $18^{\circ} 33^{\prime}$ & 45 & mire & $\mathrm{P} \%$ & 4 & Vorren (2001) \\
\hline 34 & Tjernet & $69^{\circ} 40^{\prime}$ & $18^{\circ} 57^{\prime}$ & 101 & lake & $\mathrm{P} \%$ & 3 & Fimreite et al. (2001) \\
\hline 35 & Prestvatnet & $69^{\circ} 44^{\prime}$ & $18^{\circ} 57^{\prime}$ & 96 & lake & $\mathrm{P} \%$ & 7 & Fimreite (1980) \\
\hline 36 & Nordgård & $69^{\circ} 34^{\prime}$ & $18^{\circ} 57^{\prime}$ & 22 & mire & $\mathrm{P} \%$ & 4 & Vorren (1983) \\
\hline 37 & Tønsnes & $69^{\circ} 44^{\prime}$ & $19^{\circ} 08^{\prime}$ & 19 & mire & $\mathrm{P} \%, \mathrm{PAR}$ & 5 & Høeg (2007) \\
\hline 38 & Råttuvarri & $69^{\circ} 21^{\prime}$ & $20^{\circ} 19^{\prime}$ & 100 & lake & $\mathrm{P} \%, \mathrm{PC}$ & 5 & Eronen \& Hyvärinen (1981) \\
\hline 39 & Isnestoften & $70^{\circ} 08^{\prime}$ & $22^{\circ} 59^{\prime}$ & 22 & mire & $\mathrm{P} \%$ & 2 & Vorren $(1983)$ \\
\hline 40 & Lampemyr & $69^{\circ} 55^{\prime}$ & $23^{\circ} 14^{\prime}$ & 30 & mire & $\mathrm{P} \%, \mathrm{PAR}$ & 3 & Høeg (2000) \\
\hline 41 & Trollvatnet & $70^{\circ} 03^{\prime}$ & $23^{\circ} 22^{\prime}$ & 188 & lake & $\mathrm{P} \%, \mathrm{PAR}$ & 5 & Hyvärinen (1985) \\
\hline 42 & Bruvatnet & $70^{\circ} 11^{\prime}$ & $28^{\circ} 24^{\prime}$ & 119 & lake & $\mathrm{P} \%, \mathrm{PC}, \mathrm{PAR}$ & 5 & Hyvärinen (1975) \\
\hline 43 & Mortensnes & $70^{\circ} 08^{\prime}$ & $29^{\circ} 03^{\prime}$ & 40 & mire & $\mathrm{P} \%, \mathrm{PAR}$ & 7 & Høeg (2000) \\
\hline 44 & Østervatnet & $70^{\circ} 09^{\prime}$ & $29^{\circ} 28^{\prime}$ & 148 & lake & $\mathrm{P} \%, \mathrm{PC}$ & $3^{\mathrm{H}}$ & Prentice (1981) \\
\hline 45 & Jarfjord & $69^{\circ} 40^{\prime}$ & $30^{\circ} 26^{\prime}$ & 17 & mire & $\mathrm{P} \%$ & 2 & Vorren (1983) \\
\hline 46 & Tårnet & $69^{\circ} 40^{\prime}$ & $30^{\circ} 26^{\prime}$ & 34 & mire & $\mathrm{P} \%$ & 2 & Vorren (1983) \\
\hline \multicolumn{9}{|c|}{ Inland } \\
\hline 47 & Jervjern & $68^{\circ} 52^{\prime}$ & $19^{\circ} 37^{\prime}$ & 548 & lake & $\mathrm{P} \%, \mathrm{PAR}, \mathrm{MF}$ & 11 & Jensen \& Vorren (2008) \\
\hline 48 & Gauptjern & $68^{\circ} 51^{\prime}$ & $19^{\circ} 37^{\prime}$ & 400 & lake & $\mathrm{P} \%, \mathrm{PAR}, \mathrm{MF}$ & 10 & Jensen \& Vorren (2008) \\
\hline 49 & Dalmutladdo & $69^{\circ} 10^{\prime}$ & $20^{\circ} 43^{\prime}$ & 352 & lake & $\mathrm{P} \%, \mathrm{PAR}, \mathrm{MF}$ & 11 & Bjune et al. (2004) \\
\hline 50 & Mukkavaara & $68^{\circ} 55^{\prime}$ & $21^{\circ} 00^{\prime}$ & 535 & lake & $\mathrm{P} \%, \mathrm{PC}$ & 7 & Eronen \& Hyvärinen (1981) \\
\hline 51 & Tsuolbmajavri & $68^{\circ} 41^{\prime}$ & $22^{\circ} 05^{\prime}$ & 526 & lake & $\mathrm{P} \%, \mathrm{PAR}$ & 14 & Seppä \& Weckström (1999) \\
\hline 52 & Oalgejohka & $69^{\circ} 30^{\prime}$ & $25^{\circ} 28^{\prime}$ & 260 & mire & $\mathrm{P} \%, \mathrm{PAR}$ & 3 & Høeg (2000) \\
\hline 53 & Akuvaara & $69^{\circ} 08^{\prime}$ & $27^{\circ} 41^{\prime}$ & 170 & lake & $\mathrm{P} \%, \mathrm{PC}, \mathrm{PAR}$ & 5 & Hyvärinen (1975) \\
\hline 54 & Skaidejarvri & $70^{\circ} 03^{\prime}$ & $27^{\circ} 52^{\prime}$ & 183 & lake & $\mathrm{P} \%$, PAR & 5 & Seppä (1996) \\
\hline 55 & Rautuselkä & $69^{\circ} 34^{\prime}$ & $28^{\circ} 32^{\prime}$ & 136 & lake & $\mathrm{P} \%, \mathrm{PAR}$ & 4 & Seppä (1996) \\
\hline 56 & Suovalampi & $69^{\circ} 35^{\prime}$ & $28^{\circ} 50^{\prime}$ & 104 & lake & $\mathrm{P} \%, \mathrm{PC}, \mathrm{PAR}$ & 5 & Hyvärinen (1975) \\
\hline 57 & Noatun & $69^{\circ} 10^{\prime}$ & $29^{\circ} 15^{\prime}$ & 56 & mire & $\mathrm{P} \%, \mathrm{PAR}$ & 4 & Skandfer \& Høeg (2012) \\
\hline 58 & Fosslund & $69^{\circ} 23^{\prime}$ & $29^{\circ} 42^{\prime}$ & 41 & mire & $\mathrm{P} \%, \mathrm{PAR}$ & 3 & Skandfer \& Høeg (2012) \\
\hline 59 & Melkefoss & $69^{\circ} 24^{\prime}$ & $29^{\circ} 47^{\prime}$ & 37 & mire & $\mathrm{P} \%, \mathrm{PAR}$ & 3 & Skandfer \& Høeg (2012) \\
\hline
\end{tabular}


Table 2. Main vegetation classes and vegetation sub-classes.

\begin{tabular}{|c|c|}
\hline Vegetation classes & Description \\
\hline Alder-birch forest & $\begin{array}{l}\text { Mixed forest with alder (Alnus incana) and birch (Betula pubescens) as dominant trees. It } \\
\text { is characterised by high pollen values for alder (Alnus) and birch (Betula pubescens-type). }\end{array}$ \\
\hline Birch forest & $\begin{array}{l}\text { Birch forest (Betula pubescens) with (assumed) generally tall trees ( }>10 \mathrm{~m}) \text {. It is } \\
\text { characterised by very high pollen values for birch (Betula pubescens-type). }\end{array}$ \\
\hline Birch woodland & $\begin{array}{l}\text { Open birch forest (Betula pubescens, ..var. czerepanovii, ..var. appressa), with (assumed) } \\
\text { generally small trees }(<10 \mathrm{~m}) \text {. It is characterised by high pollen values for birch (Betula } \\
\text { pubescens-type). }\end{array}$ \\
\hline Heathland & $\begin{array}{l}\text { Open vegetation dominated by dwarf-shrubs, primarily crowberry (Empetrum nigrum) but } \\
\text { bilberry (Vaccinium myrtillus), bog bilberry (Vaccinium uliginosum) and dwarf-birch } \\
\text { (Betula nana) are also common, as well as grass (Poaceae). It is characterised by high } \\
\text { pollen values for crowberry (Empetrum-type, Ericales-type) and low to moderate values } \\
\text { for billberry/ bog billberry (Vaccinium-type, Ericales-type), grasses (Poaceae) and dwarf } \\
\text { birch (Betula nana-type). }\end{array}$ \\
\hline Dry heathland & $\begin{array}{l}\text { Similar taxa as in heathland but more sparse vegetation. Crowberry (Empetrum nigrum) } \\
\text { are common but billberry (Vaccinium myrtillus) occur more infrequently. Grasses } \\
\text { (Poaceae) and dwarf birch (Betula nana-type) have a higher proportion in the pollen } \\
\text { records. }\end{array}$ \\
\hline Grass-heathland & $\begin{array}{l}\text { As heathland but with a larger component of grass (Poaceae, } \sim>20 \% \text { pollen) and } \\
\text { commonly richer in herbs. }\end{array}$ \\
\hline Pine forest & $\begin{array}{l}\text { Pine (Pinus sylvestris) forest. It is characterised by very high pollen values for pine } \\
\text { (Pinus). }\end{array}$ \\
\hline Pine-birch forest & $\begin{array}{l}\text { Mixed forest/woodland with pine (Pinus sylvestris) and birch (Betula pubescens) as } \\
\text { dominant trees. It is characterised by high pollen values for pine (Pinus) and birch (Betula } \\
\text { pubescens-type). }\end{array}$ \\
\hline Shrub tundra & $\begin{array}{l}\text { As heathland but with much more sparse vegetation and including willow (Salix sp.) and } \\
\text { sorrels (Rumex/Oxyria). Willow (Salix) and sorrels (Rumex-type, Oxyria-type) are more } \\
\text { common in the pollen assemblage. PAR, if available, is low. }\end{array}$ \\
\hline Steppe tundra & $\begin{array}{l}\text { Very sparse herb- and graminoid vegetation characterised by pollen from mugworth } \\
\text { (Artemisa), sorrels (Rumex/Oxyria) and goosefoots (Chenopodiaceae). PAR, if available, } \\
\text { is low. }\end{array}$ \\
\hline Tundra & $\begin{array}{l}\text { Sparse open vegetation. Grasses and sorrels (Rumex/Oxyria) are common among vascular } \\
\text { plants. Willow (Salix sp.) and dwarf birch (Betula nana) are present. It is characterised by } \\
\text { high relative pollen values for grasses (Poaceae) and sorrels (Rumex-type, Oxyria-type) } \\
\text { and low values for willow (Salix) and and dwarf birch (Betula nana-type). PAR, if } \\
\text { available, is low. }\end{array}$ \\
\hline \multicolumn{2}{|l|}{ Vegetation sub-classes } \\
\hline -heath type & $\begin{array}{l}\text { Forest/woodland with field layer dominated by heaths, most commonly crowberry } \\
\text { (Empetrum nigrum) and billberry (Vaccinium myrtillus). }\end{array}$ \\
\hline -meadow/ferns type & $\begin{array}{l}\text { Larger element of herbs. In forest/woodland ferns are common (monolete fern spores, } \\
\text { Gymnocarpium-type spores). In grass-heathland most dwarf-shrubs (Ericales, Betula } \\
\text { nana) are replaces by herbs, i.e. grass-meadow. }\end{array}$ \\
\hline -tall-herb type & $\begin{array}{l}\text { Similar to the meadow/ferns sub-class but with a larger elements of tall herbs, especially } \\
\text { meadowsweet (Filipendula ulmaria). }\end{array}$ \\
\hline - mire type & $\begin{array}{l}\text { Heatland with a larger element of typical mire plants, especially half-grasses (Cyperaceae) } \\
\text { and/or cloudberry (Rubus chamaemorus). Peat moss (Sphagnum) and mire herbs as } \\
\text { meadow-rue (Thalictrum) may also be more frequent. }\end{array}$ \\
\hline
\end{tabular}


Table 3. Schematic vegetation development in northernmost Fennoscandia. The outer coast and inner fjord area have been divided into south-western and northern sub-sets (see Fig. 2). +HI = human impact affecting the type of vegetation with reduced tree-cover and increased abundance of herbs and grasses; (late) $=$ after $\sim 1700 \mathrm{CE}$.

\begin{tabular}{|c|c|c|c|c|c|}
\hline \multirow{2}{*}{$\begin{array}{l}\text { Age } \\
\text { (cal. a BP) }\end{array}$} & \multicolumn{2}{|c|}{ Outer coast } & \multicolumn{2}{|c|}{ Fjord area } & \multirow{2}{*}{ Inland } \\
\hline & SW & $\mathrm{N}$ & & $\mathrm{N}$ & \\
\hline $1000-0$ & \multirow{5}{*}{ Birch woodland } & \multirow[t]{2}{*}{$+\mathrm{HI}$ (late) } & $\frac{\mathrm{SW}}{+\mathrm{HI}}$ & $+\mathrm{HI}$ & \multirow{4}{*}{$\begin{array}{l}\text { Birch woodland / } \\
\text { Mixed birch-pine } \\
\text { forest }\end{array}$} \\
\hline $2000-1000$ & & & & \multirow{3}{*}{$\begin{array}{c}\text { Birch } \\
\text { woodland }\end{array}$} & \\
\hline $3000-2000$ & & \multirow[t]{2}{*}{ Heathland } & & & \\
\hline $4000-3000$ & & & & & \\
\hline $5000-4000$ & & \multirow{3}{*}{$\begin{array}{l}\text { Birch woodland } \\
\text { / Heathland }\end{array}$} & \multirow{4}{*}{\multicolumn{2}{|c|}{$\begin{array}{l}\text { Birch forest, meadow/fern } \\
\text { type / Mixed birch-pine } \\
\text { forest }\end{array}$}} & \multirow{4}{*}{$\begin{array}{l}\text { Pine forest / Mixed } \\
\text { birch-pine forest }\end{array}$} \\
\hline $6000-5000$ & \multirow{5}{*}{$\begin{array}{l}\text { Birch forest, } \\
\text { meadow/fern } \\
\text { type }\end{array}$} & & & & \\
\hline $7000-6000$ & & & & & \\
\hline $8000-7000$ & & \multirow{3}{*}{$\begin{array}{l}\text { Birch woodland, } \\
\text { meadow/fern } \\
\text { type }\end{array}$} & & & \\
\hline $9000-8000$ & & & \multirow{3}{*}{\multicolumn{2}{|c|}{$\begin{array}{l}\text { Birch forest, } \\
\text { meadow/fern type }\end{array}$}} & Birch forest, \\
\hline $10000-9000$ & & & & & meadow/fern type \\
\hline $11000-10000$ & \multicolumn{2}{|c|}{ Shrub tundra / Birch woodland } & & & Shrub tundra \\
\hline $12000-11000$ & \multicolumn{2}{|c|}{ Shrub tundra } & \multicolumn{2}{|c|}{ Shrub tundra } & Glaciated \\
\hline $13000-12000$ & \multicolumn{2}{|c|}{ Steppe tundra } & \multicolumn{2}{|c|}{ Steppe tundra / Glaciated } & Glaciated \\
\hline $14000-13000$ & \multicolumn{2}{|c|}{ Tundra } & \multicolumn{2}{|c|}{ Tundra / Glaciated } & Glaciated \\
\hline
\end{tabular}




\begin{tabular}{|c|c|c|c|c|c|c|}
\hline \multirow[b]{2}{*}{ Age (cal. BP) } & \multirow{2}{*}{$\begin{array}{l}\text { Lateglacial } \\
14000- \\
11700 \\
\end{array}$} & \multicolumn{2}{|c|}{ Early Holocene } & \multicolumn{2}{|c|}{ Middle Holocene } & \multirow{2}{*}{$\begin{array}{l}\text { Late Holocene } \\
4000- \\
\text { present }\end{array}$} \\
\hline & & $\begin{array}{l}11700- \\
10000\end{array}$ & $\begin{array}{l}10000- \\
8000\end{array}$ & $\begin{array}{l}8000- \\
6000\end{array}$ & $\begin{array}{l}6000- \\
4000\end{array}$ & \\
\hline \multicolumn{7}{|l|}{ Climate conditions } \\
\hline Summer insolation ${ }^{1}$ & High & Very high & Very high & High & Moderate & Low \\
\hline Norwegian Current $^{2}$ & Weak & Increasing & Strong & Strong & Decreasing & Weak \\
\hline Climate trend/type ${ }^{3}$ & Variable & Warming & Variable & Stable & Cooling & Variable \\
\hline Effective precipitation $^{4}$ & Dry & Moderate & Wet & Dry & Dry & Wet \\
\hline July temperature ${ }^{5}$ & Cold & Cool & Warm & Very warm & Warm & Moderate \\
\hline$\Delta$ July temp. $\left({ }^{\circ} \mathrm{C}\right)^{5}$ & $-5 \pm 3$ & $-1 \pm 2$ & $+1 \pm 1$ & $+1.5 \pm 0.5$ & $+1 \pm 0.5$ & \pm 0.5 \\
\hline $\begin{array}{l}\text { Characteristic } \\
\text { vegetation }\end{array}$ & $\begin{array}{l}\text { Tundra } \\
\text { (glaciated) }\end{array}$ & $\begin{array}{l}\text { Shrub- } \\
\text { tundra }\end{array}$ & $\begin{array}{l}\text { Birch-fern } \\
\text { forest }\end{array}$ & $\begin{array}{l}\text { Pine-birch } \\
\text { forest }\end{array}$ & $\begin{array}{l}\text { Pine-birch } \\
\text { forest }\end{array}$ & $\begin{array}{l}\text { Birch-crowberry } \\
\text { woodland }\end{array}$ \\
\hline
\end{tabular}

${ }^{1}$ Summer insulation as relative diurnal summer insolation $>500 \mathrm{~W} \mathrm{~m}^{-2}$ at $70^{\circ} \mathrm{N}$ (Huybers 2006 ).

${ }^{2}$ Norwegian current indicate the Norwegian Atlantic Current surface water heat transport (Sea Surface Temperature; Andersen et al. 2004; Chistyakova et al. 2010.

${ }^{3}$ Climate trend/type describe the general climatic variation or trend within the period, same references as the other climatic parameter.

${ }^{4}$ Effective precipitation is precipitation minus evapotranspiration (Hyvärinen \& Alhonen 1994; Eronen et al. 1999; Hammarlund et al. 2002; Korhola et al. 2005; Birks et al. 2012, 2014; Vorren et al. 2012; Balascio \& Anderson 2016.)

${ }^{5}$ July temperature and $\Delta$ July temperature describe the relative and absolute change in July temperature. The \pm is an estimate of the range in temperature expected to find within the period and between the most consistent half of the investigations (Seppä 1996; Kullman 1999;

Barnekow 2000; Bigler et al. 2002, 2003; Hammarlund et al. 2002; Seppä et al. 2002a,b, 2009; Jensen \& Vorren 2008; Huntley et al. 2013; Birks et al. 2012, 2014; Kullman \& Öberg 2015). 